\title{
Zülfü Livaneli’nin Mutluluk Romanı Karakterlerinin Toplumsal Cinsiyet Bağlamında İncelenmesi
}

\author{
ÖZLEM HASKAN AVCI* \\ haskan@hacettepe.edu.tr
}

\author{
MUHARREM KOÇ*** \\ muharrem.koc@hacettepe.edu.tr
}

\author{
ÖZNUR BAYAR *** \\ oznur.bayar@hacettepe.edu.tr
}

\begin{abstract}
Özet: Toplum ve bireylerin hayatında her zaman var olmuş ve var olmaya devam edecek olan edebiyat ve edebi eserler, topluma özgü kültürel öğelerin anlatıldığı, ifade edildiği alanlardır. Bir edebi eser türü olarak romanlar, birçok açıdan toplumun ve o toplumdaki bireylerin özelliklerini yansıtmaktadır. Bu çalışmada, Türkiye'deki farklı erkeklik ve kadınlık hallerini resmeden Zülfü Livanelinin mutluluk romanında yer alan karakterlerin, toplumsal cinsiyet rolleri açısından incelenmesi amaçlanmıştır. Bir nitel araştırma yöntemi olan kültürel analiz kapsamında söylem analizi yapılmıştır. Romanda, amcası tarafından tecavüze uğrayan Meryem'in "töre" anlayışından ötürü öldürülmesinin gerektiği ve yine bu anlayıştan ötürü bu görevin, Meryem'in amcasının oğlu olan Cemal'e uygun görülmesi anlatılmaktadır. Türkiye'de kadına yönelik cinsiyet ayrımcilı̆̆ın resmeden, kadının namus abidesi ve erkeğin de namus bekçisi haline getirilişini anlatan romanda, toplumsal cinsiyet rollerinin kadın ve erkek üzerinde nasıl baskı oluşturduğu yansıtılmaktadır. Bu çalışma sonucunda, romanın toplumsal cinsiyet konusuyla ilgili, özellikle Türkiye'de kadının konumu ve namus algisı ile ilgili derinlemesine bir kültürel görünüm sunduğu anlaşılmıştır. Çalışma ile Türkiye'de toplumsal cinsiyet ve toplumsal cinsiyet rolleri ele alınarak, başta bu konular ile ilgilenenler olmak üzere sosyal bilimlere ilgi duyanların, edebiyatseverlerin ve en genelde toplumun duyarlılı̆̆ının artırılması amaçlanmışttr.
\end{abstract}

Anahtar Kelimeler: Zülfü Livaneli, Mutluluk, toplumsal cinsiyet, toplumsal cinsiyet rolü.

\section{Giriş}

Bütün toplumlarda doğuştan gelen biyolojik farklılıklar kültürel olarak yorumlanıp değerlendirilir. Böylece kadınlar ve erkeklerin hangi davranış ve faaliyetleri yapabileceklerine, hangi haklara ve güce kimin ne derece sahip olduğuna veya sahip olması gerektiğine ilişkin toplumsal beklentiler geliştirilir. Bu beklentiler, toplumdan topluma ve aynı toplum içinde bir toplumsal kesimden diğerine kısmen değişse de özünde ortak noktalar vardır. Toplumsal cinsiyet temelli asimetrinin, yani farklılıklar ve eşitsizliklerin varlığı bu özü oluşturmaktadır. ${ }^{1}$ Toplumsal cinsiyet, biyolojinin kodladığı maddi bedenlere manevi anlamlar yükleyerek onları kültürel olarak tanımlamak ve

\footnotetext{
* Yrd. Doç. Dr., Hacettepe Üniversitesi, Eğitim Fakültesi, PDR Anabilim Dalı.

** Arş. Gör., Hacettepe Üniversitesi, Eğitim Fakültesi, PDR Anabilim Dalı.

*** Arş. Gör., Hacettepe Üniversitesi, Eğitim Fakültesi, PDR Anabilim Dalı.

1 Yıldız Ecevit, “Toplumsal Cinsiyetle Yoksulluk İlişkisi Nasıl Kurulabilir? Bu İlişki Nasıl Çalışılabilir?” C.Ü. Tip Fakültesi Dergisi 25/4 (2003 Özel Ek): 83.
} 
ayırmaktır. Kadın ve erkeği, kadınlık ve erkeklik denen rol ve statüler bütünüyle özdeşleştirmektir. Bu ayrım, kadının aleyhine birçok eşitsizliğin doğmasında başrolü oynamaktadır. ${ }^{2}$

İnsanlar dişi veya erkek cinsiyeti ile doğarlar ancak yetiştirilirken toplumun cinsiyetlerine özgü beklediği roller çerçevesinde kız veya erkek çocuk olmayı öğrenerek büyürler. ${ }^{3}$ Biyolojik cinsiyet farklılıkları öğrenilmemiş, doğuştan getirilen özellikler bakımından kadınlarla erkekler arasında gözlenen farklılıklarken; toplumsal cinsiyet farklılıkları öğrenilen, sosyalleşme sürecinde kazanılan özellikler bakımından insanlar arasında gözlenen farklılıklardır . Büyürken rolleri öğretilmiş olan kadın ve erkekler toplumun beklentilerine uygun davranma yönünde çoğu kez farkında bile olmadıkları, doğalmış gibi algılanan çeşitli yaptırımlarla karşılaşmaktadirlar. $^{5}$

Scott'a ${ }^{6}$ göre toplumsal cinsiyet, cinsiyeti olan bir bedene zorla giydirilen toplumsal bir elbisedir. Cinsiyet rolünün öğrenilmesi, toplumsallaşma ile mümkün olmaktadır. Böylece kadınlık karakteri kadın rolüne, erkeklik karakteri de erkek rolüne toplumsallaşma ile yerleştirilmektedir. Bu nedenle de kız ve erkek çocuklarına farklı davranılır. ${ }^{7}$ Cinsiyet, bireylerin kendilerini nasıl görmeleri ve diğer bireylere karşı nasıl davranmaları gerektiğini belirlemekte ve çoğu zaman sosyal farklılaşmaya temel oluşturmaktadır. Bu anlamda cinsiyet eşitsizliği, toplumda tabakalaşma sisteminin önemli bir öğesidir. Sosyologlar genellikle cinsiyet eşitsizliğini gücün, maddi refah ve prestijin dağılımı açısından kadınlar ve erkekler arasındaki hiyerarşik asimetriler olarak tanımlamaktadırlar. ${ }^{8}$ Cinsiyet eşitsizliği, bir cinsiyetin diğer cinsiyet üzerinde baskın ya da diğerine göre üstün olduğu inancına dayanan bir ideoloji olan "cinsiyetçilik" aracılığı ile açıklanmaktadır. ${ }^{9}$ Cinsiyetçilik ve sözü edilen asimetrinin, uzun yıllardır erkeğin lehine olacak biçimde geliştiği söylenebilir.

Kadınlar, tarih boyunca cinsiyet ayırımcılığı ve eşitsizliklerle karşı karşıya kalmışlar, erkeklerden daha düşük statüde görülmüşler ve erkeklere kıyasla daha az hak ve şansa sahip olmuşlardır. Bunda toplumsal cinsiyet rollerinin ve bu rollerin öğrenildiği sosyalleşme sürecinin etkisi büyüktür. ${ }^{10}$ Toplumsal cinsiyet rollerinin değişiminde ise, ailenin yanı sıra, okul, din kurumları, medya kuruluşları gibi sosyal kurumlara

2 Orhan Bingöl, “Toplumsal Cinsiyet Olgusu ve Türkiye'de Kadınlık”. KMÜ Sosyal ve Ekonomik Araştırmalar Dergisi 16 (2014 Özel Sayı I): 108.

3 Füsun Terzioğlu, Lale Taşkın, "Kadının Toplumsal Cinsiyet Rolünün Liderlik Davranıșlarına ve Hemșirelik Mesleğine Yansımaları”, C.Ü. Hemşirelik Yüksekokulu Dergisi 12/2 (2008): 63.

4 Zehra Yaşın Dökmen, Toplumsal Cinsiyet: Sosyal Psikolojik Açıklamalar (İstanbul: Remzi Kitabevi, 2015$), 25$. 5 Gönül Demez, Kabadayıdan Sanal Delikanlıya Değişen Erkek İmgesi (İstanbul: Babil Yayınları, 2005), 34.

6 Joan W. Scott, Toplumsal Cinsiyet: Faydalı Bir Tarihsel Analiz Kategorisi, çev., Aykut Tunç Kılıç (İstanbul: Ayrıntı Yayınlar1, 2007), 11.

7 Richard W. Connell, Toplumsal Cinsiyet ve İktidar, Toplum, Kişi ve Cinsel Politika, çev., Cem Soydemir (İstanbul: Ayrintı Yayınları, 1998), 79.

8 Monica Boyd, “Gender Inequality: Economic and Political Aspects", edt., Robert J. Brym, New Society: Sociology for the 21st Century, (Toronto: Harcourt Brace\&Company, 1998), 189.

9 Thomas J. Sullivan, Introduction to Social Problems, Sixth Edition (Boston: Pearson Education, 2003), 224.

10 Sevda Demirbilek, "Cinsiyet Ayırımcılığının Sosyolojik Açıdan İncelenmesi”, Finans, Politik \& Ekonomik Yorumlar 44/511 (2007): 25. 
da önemli görevler düşmektedir. ${ }^{11}$ Dolayısıyla, bireylerde ve genel olarak toplumda, toplumsal cinsiyet rolü ile ilgili farkındalığın geliştirilmesine ihtiyaç olduğu düşünülmektedir.

\section{Yöntem}

Sanat, özellikle de edebiyat, insanın ikinci doğası olan kültür dünyasında yaşanan çıkmazlara işaret etmek gibi temel bir işleve sahiptir. Bilimsel yazı olanı, olup biteni açıllarken, edebiyat ürünleri olabilecek olanları ortaya koyar. ${ }^{12}$ Toplumsal cinsiyetle ilgili temel konular ve kavramlardan pek çoğunun, Zülfü Livaneli’nin Mutluluk adlı eserinde örneklerini bulduğu dikkati çekmektedir. Toplumsal cinsiyet rollerinin, Türkiye'de erkekliğe ve kadınlığa yüklenen anlamların, erkek ve kadınla ilgili kalıp yargıların karakterlerin konuşmalarında veya yaşantılarında açıkça göze çarptığı bu eserin toplumsal cinsiyet konusunun anlaşılmasında kullanılabileceği düşünülmektedir. Romanın, özellikle Türkiye’nin farklı bölgelerinde kadının ve erkeğin konumsal farklılıklarına getirdiği bakış açısı, toplumsal cinsiyetin kadını ve erkeği nasıl etkilediğini anlamada farklı bir perspektif sunabilir.

Zülfü Livaneli tarafından yazılmış ve 92 defa basımı yapılmış, aynı zamanda filme çekilmiş olan “Mutluluk” romanı, 2007’de Barnes \& Noble Büyük Yazar Ödülü’ne layık görülmüştür. Roman, her biri mutluluğu arayan üç farklı karakter üzerine kurgulanmıştır. Şeyh amcası tarafından tecavüze uğramış ve aile tarafından öldürülmesine karar verilmiş; töre cinayetine kurban gitmek üzere olan Meryem; ailesi tarafından Meryem'i öldürmekle görevlendirilmiş, zorlu geçen askerliğini yeni tamamlamış kuzeni Cemal ve İstanbullu tanınmış bir aydın olan Prof. Dr. İrfan Kurudal. Cemal, Meryem’i öldürmek üzere İstanbul'a götürür. Cemal burada Meryem’i öldürmeyi henüz başaramazken, İstanbul'daki hayatından bunalmış, sahip olduğu her şeyi geride bırakarak teknesiyle yolculuğa çıkan İrfan Kurudal ile yolları bir biçimde kesişir. Romanda üç kahramanın kesişen kaderleri ve tanıklık ettikleri yaşantılar aracılığıyla yazar, temelde Türkiye’nin bir portresini çizmiştir. Roman, Türkiye'de farklı sınıfların cinsiyet kültürüne de ışık tutmaktadır. Türkiye'de farklı erkeklik ve kadınlık hallerini resmeden romanın son baskısis ${ }^{13}$, bu dikkat çeken yönü ile toplumsal cinsiyetle ilgili temel kavramlar bağlamında incelenmek istenmiştir. Bir nitel araştırma yöntemi olan kültürel analiz kapsamında söylem analizi yapılmıştır. Çalışma ile Türkiyede toplumsal cinsiyet ve toplumsal cinsiyet rolleri ele alınarak, başta bu konular ile ilgilenenler olmak üzere sosyal bilimlere ilgi duyanların, edebiyatseverlerin ve en genelde toplumun duyarlılı̆̆ının artırılması amaçlanmıştır.

\section{Bulgular ve Yorumlanması}

Bu bölümde Mutluluk Romanı’na ait kesitler, toplumsal cinsiyet bağlamında değerlendirilmiştir. Roman Meryem’in, amcası tarafından tecavüze uğraması ve olayın

11, James William Coleman ve Harold R. Kerbo, Social Problems: A Brief Introduction, Second Edition, (New Jersey: Prentice Hall, 2003), 277.

12 Galip Akın, “Toplumsal Cinsiyet ve Edebiyat”, Erkekler, haz., Ayșe Akaltun (İstanbul: Notabene Yayınları, 2015), 74.

13 Zülfü Livaneli, Mutluluk (İstanbul: Doğan Kitap, 2015; 92. bsm). 
ardından yaşadığı şokla kaçarken yakalanıp taş evin altındaki izbeye kapatılması ile başlamaktadır. Meryem kendisine tecavüz edenin amcası olduğunu söyleyememiştir. Amcası ise, bu konudan asla söz etmemekte; Meryem'i suçlayan ve kendisini yok sayan bir tavır içine bürünmektedir. Tecavüzün bütün yükü ve mağduriyetinin kad1nın omuzlarına yüklendiğini anlatan bazı kesitlere rastlanmaktadır:

Küçük üvey anası Döne, ona arada bir yemek getiriyor, sonra da tek başına, bahçenin kuytu köşelerinde ihtiyaçlarını gidermesine izin veriyordu. İște hepsi bu kadar! Dünyayla başka ilişkisi kalmamıştı Meryem'in. Daha kendisini ne kadar burada tutacaklarını, ne yapacaklarm, hakkında ne gibi bir karara varacaklarını bilemiyordu. Birkaç kere, yaşı kendisine yakın Döne’ye sordu ama o kara yürekli genç kadın, "Sen yaptığının cezasının ne olduğunu bilirsin!” diyerek onu daha da çok korkutmaktan başka bir yardımda bulunmadı.

Roman karakteri Döne’nin yaptığg gibi, Türkiye'de pek çok zaman tecavüzün kurbanı cezalandırılırken, faili hiç zarar görmeden yaşamına devam edebilmektedir. Toplumsal cinsiyet rollerine göre, kadın kendini koruyamamakla suçludur; erkek ise taşıdığ erkeklikle iktidarın mutlak sahibi olup, sorgulanmaz. Romanda anlatılan Meryem'in öyküsü, aslında Türkiye'de tecavüzle ilgili geleneksel anlayışa da bir eleştiri niteliği taşımaktadır. Türkiye’de, diğer pek çok ülkede olduğu gibi, tecavüz kadınların sorunu olarak algilanmaya devam etmektedir. Son dönemde meydana gelen tecavüz olaylarında bile, "kadının gece o saatte ne işi vardı" gibi söylemlerle olayın kadına yüklenmeye çalışılması, geleneksel erkek egemen düşünce yapısının bir yansıması olarak görülmektedir. Konuyla ilgili kültürümüzde deyimler ve atasözleri dahi kad1nı hedef alabilmektedir. Romanda geçen bir bölüm tecavüze uğrayan kadına yönelik anlayışı resmetmektedir:

Cemal kafa sallıyordu ama babasının ne dediğinin farkında değildi pek. "Kancık it kuyruk sallamazsa, erkek it arkasindan dolanmaz. Kimbilir tenhalarda neler yaptı ki başına bunlar geldi."

$\mathrm{Bu}$ gibi atasözlerimizde, deyişlerimizde yer alan bazı ifadeler aslında mitleri; yani yaygın yanlış inanışları da aktarabilmektedir. Tecavüz olgusuna ve tecavüz mağdurlarına ilişkin yanlış inanışlar ise "tecavüz mitleri” olarak literatürde yerini almaktadır. Çoklar ve Gülgün-Meşe (2014) tarafından tecavüz mitleri "tecavüz, tecavüz kurbanları ve tecavüz failleri hakkındaki önyargılı, kalıp yargı haline gelmiş ve yanlış inançlar” olarak tanımlanmakta ve söz konusu mitlerin, erkeğin kadına yönelik cinsel saldırganlığını inkâr etme ya da meşrulaştırmaya hizmet ettikleri ve daha geniş bir inanç sistemiyle ilişkili oldukları vurgulanmaktadır. Söz konusu mitlerin Türkiye'de de yaygın biçimde kabul gördüğünü gösteren araştırmalar mevcuttur. ${ }^{14}$ Cinsel şiddet, sosyalleşme sürecinde öğrenilmiş ve toplumca paylaşılan önyargılardan dolayı olağan kabul edilir veya çoğunlukla ona göz yumulur. ${ }^{15}$ Ataerkil sistem içinde, er-

14 N. Sakallı-Uğurlu, S.Z. Yalçın ve P. Glick, “Ambivalent Sexism, Belief in a Just World, and Empathy as Predictors Of Turkish Students' Attitudes Toward Rape Victims” Sex Roles, 57/11-12 (2007): 890.

15 Tuğba Eker ve Eda Erdener, “Tecavüze İlişkin Kültürel Mitler ve Mitlerin Kabul Edilmesine Etki Eden Faktörler” Türk Psikoloji Yazıları, 14/28 (Aralık 2011): 61. 
kekleri, kadınları korumakla yükümlü tutan şey, namuslarını kendi başlarına korumaları konusunda kadınlara güvenilmeyeceği inancıdır. Böyle bir durumda kirlenen yalnızca kadının namusu değil, aile fertlerindeki tüm erkeklerin namusudur. ${ }^{16}$ Romanda, sözü edilen erkekliğin namus arayışı çarpıcı biçimde ortaya konmaktadır:

"Amcasını, sadece o evde, o kasabada değil her yerde sayarlardı. Ellerinde adaklarla, hediyelerle ziyaretçiler gelir, amcasının elini öper, ona büyük saygı gösterirlerdi. Tarikat şeyhi olduğu için, o tepenin arkasındaki İstanbul' da bile müritleri vardı onun. İzbede korku içinde titreyerek otururken bazen, "Kapatın şu rezil, namussuz, ahlaksız fahişeyi!" diyerek kendisini buraya kapattıran amcasının öfke dolu sesi geliyordu kulağına; bu, daha çok titremesine neden oluyordu. Döne’nin söylediği gibi, onun yüzünden "ailesinin şerefi iki paralık olmuş" ve kasabada insan içine çıkacak yüz kalmamıştı hiçbirinde. "

Meryem'in kendisi gibi birer kadın olan teyzesi ve üvey annesi Döne tarafından aşağılanması ve tecavüzle ilgili olarak suçlanması dikkat çekicidir. Türkiye’de toplumsal cinsiyet rollerini içselleştiren pek çok kadın da hemcinsine erkekten yana bir ayrımcılık uygulamaktadır. Taş’a ${ }^{17}$ göre, erkeklerin üstünlüğünde kadının da rolü büyüktür. Kadınlar oğullarını, kızlara karşı her zaman üstün görerek, erkeğe hizmet edilmesine ilişkin buyrukları hep "kıza” vererek, var olan erkek iktidarını sürdürürler. Erkeklerin zorba, anlayışsız, dayakçı, tecavüzcü olmalarında kadınların- annelerin- de bir payı olabilmektedir. Romanda kadının kadını ezdiği gerçeği açıkça gözler önüne serilmektedir:

"Başına bu iş gelen kızlara ne yaparlar?" diye sormuştu saf saf. Döne de, "Ístanbul'a gönderirler!” deyivermişti. "Daha önce de iki-üç kız İstanbul'a gitti.” O zaman, içindeki korku biraz hafiflemişti; demek o tepenin arkasına gidecekti, cezası buydu. Ama bunları söylerken Döne' nin yüzünde beliren o, "Sen belanı buldun kızım!" bakışı da neydi öyle. Kendisini günahı kadar sevmeyen Döne’nin yüzündeki o yılan bakışı kanını dondururdu hep. Şimdi de öyle olmuştu. Döne ayrılırken, "Tabii kendini asanlar dışında!" diye ekledi. "Bir ip bulup bu işi kökten halledenler de görüldü.” Meryem, o gittikten sonra hep orada durduğunu bildiği örme iplere, kangal kangal öbeklenmiş halatlara içi ürpererek baktı. Onu buraya, kendisini asması için mi kapatmışlardı acaba? İzenin tavanındaki ahşap kirişler, hatıllar ve yerde duran ipler, bu iş için biçilmiş kaftandı. Bir insan kendisini asacaksa, en uygun yer olmalıydı bu izbe.

Döne’nin sözleri aslında tecavüz kurbanı olan Meryem’in mağduriyetini daha da artırmaktadır. Cinsel suç mağdurlarının, mağdurlar arasında en yoğun acı çekenler olduğunu ifade eden Sokullu Akınc1 ${ }^{18}$, bunların diğer suçlara oranla daha yüksek oranda siyah sayı olarak kaldığını belirtmektedir. Burada da en önemli neden toplumsal önyargılar ve gelenekselleşmiş toplumsal cinsiyet rollerinin baskınlığıdır. Bu

16 Ruşen Işık ve Nuray Sakallı Uğurlu, "Namusa ve Namus Adına Kadına Uygulanan Şiddete İlişkin Tutumlar Ölçeklerinin Öğrenci Örneklemiyle Geliştirilmesi” Türk Psikoloji Yazıları, 12/24 (Aralık 2009): 17.

17 Murat Taş, “Mutfak”, Erkekler, haz., Ayşe Akaltun (İstanbul: Notabene Yayınları, 2015), 67.

18 Füsun Sokullu Akınc1, Kriminoloji (İstanbul: Beta Basım Yayım, 2011), 75. 
suça maruz kalan kadınlar, toplum tarafından mağduru kışkırttığı suçlaması ile karşı karşıya kalabildikleri için uğradıkları fiili saklarlar. Romanda Meryem'in de başına gelenleri saklaması hatta hatırlayamaması pek çok mağdurun yaşadıklarına bir örnek oluşturmaktadır:

Ya başına bir örtü, bir çuval geçirmişler ve yüzlerini göstermeden işlerini bitirmişlerdi ya da kız iyice sersemlediği için, gerçekten hiçbir şey hatırlamıyordu. Gerçi hatırlasa da faydası olmayacaktı ki.

Romanda görüldüğü gibi, kadın aslında erkek için, erkekliğin devamı için var olan bir nesne gibidir. Türkiyede kadın, başta kocası olmak üzere baba, oğul ve erkek kardeşin namusunu, adını ve onurunu korumak zorunda olan, onlara ait bir nesne konumundadır. ${ }^{19}$ Türkiye'de bireylerin, kadınların bakireliği ile namusu eşleştirdiğine dair araştırmalar da mevcuttur. ${ }^{20} \mathrm{~S}_{1} \mathbf{r}^{21}$ tarafından yapılan araştırmada, namus nedir sorusuna katılımcıların \% 33'ü “karım, bacım, annemdir” yanıtını vermiştir. Namussuzluk nedir sorusuna ise kadının zina yapması, bekâretini kaybetmesi, açık gezmesi (kısa kollu elbiseler, kısa etek giymesi), erkeklerle konuşması, ailenin istemediği kişi ile evlenmesi şeklinde yanıtlar verilmiştir. Bu araştırmada katılımcıların \% 30’u namusu korumanın, babanın, ağabeyin, \%21'i ise ailedeki tüm erkeklerin görevi olduğunu; namusla ilgili olaylarda kulak kesme, burun kesme, saç kazıma gibi cezalandırma yöntemlerinin uygulanabileceğini; \%64’ü de bu cezayı verecek kişinin kadının kocası olması gerektiğini belirtmişlerdir. "Namusunu kaybeden” kadına verilecek cezalarla ilgili yorumlar, romanda adeta bu araştırmanın sonucunu ve kültürümüzü yansıtır gibi ele alınmıştır:

O, küçük hıçkırıklarla ă̆ladığı sırada erkekler, üst kattaki sofada konuşuyorlardi. Amcası son zamanlarda garip huylar edinen ve askerlikten farkl bir insan olarak dönen oğlunu karşısına almış, "Senin gelişin bizi bir parça kurtardı," diye anlatıyordu. "Bu kız yüzünden şerefimiz iki paralık oldu, insanların yüzüne bakamaz hale geldik ama senin kahraman gibi dönüşün. Babasının sözleri bölük pörçük kulağına çalınıyordu: "Bu hale düşecek aile değildik!" diyordu. "Ama ne yaparsin ki kader," diye devam ediyordu. Cemal susuyordu. Cemal!" diyordu adam, "Istanbul'a gitmen gerekiyor! Bu kız hem Allah indinde hem de kul gözünde suçludur. Törelerimizi iyi bilirsin. Bu pisliği temizlemek sana düşüyor. Biliyorum askerden yeni geldin ama daha fazla beklemeye tahammülümüz kalmadı. Herkes üstümüze gülüyor, gizli gizli dedikodu yapıyorlar. Ailemizde bu işi yapabilecek yaşta başka bir erkek yok.”

Romanda dikkat çekildiği gibi, namus, bireylerin yaşam nedeni olabilmekte ve bu uğurda canlar alınabilmektedir. Neredeyse her gün günlük gazetelerde namus adına

19 Naile Bilgili ve Gülşen Vural, "Kadına Yönelik Şiddetin En Ağır Biçimi: Namus Cinayetleri”, Anadolu Hemşirelik ve Sağlik Bilimleri Dergisi 14/1 (2011): 66.

20 Gaye Okyay, “Women Victimization: In The Case of Family Honor in Turkey” (yüksek lisans tezi, Orta Doğu Teknik Üniversitesi, 2007), 90.

21 Aytekin Sır, "Namusun Algılanışı", İstersek Biter, haz., Aksu Bora (İstanbul: KA-MER Vakfı Yayınları, 2011), 60. 
kadına uygulanan şiddetle ilgili haberler yer almaktadır. ${ }^{22}$ Bir ailenin ya da erkeğin namusu aile içindeki kadınların cinsel içerikli davranışları ile oldukça ilintili olarak algılanmaktadır. Bu durumda bir kadın kendi namusunu korur iken ailesinin namusuna da halel getirmemeye çabalamaktadır. Kısacası, namus kavramı kadının cinselliği kontrol altında tutulmaya çalışılarak anlamlandırılmaktadır. ${ }^{23}$ Erkeğe erkekçe tutumlar takınma ve erkekçe davranma (çalışma, evin geçimini üstlenme, eş, anne ve kız kardeşleri koruma) rolü yüklerken, kadına da cinsel sakınma (ailenin onayladığı erkekle evlenme, eş ve kardeş dışında başka erkeklerle konuşmama, iletişim kurmama gibi) roller yüklenmektedir. ${ }^{24}$

Romanda Cemal'den ailesinin "şerefini ve namusunu” kurtarmak için Meryem’i öldürmesi beklenmektedir. Tezcan'a ${ }^{25}$ göre, geleneksel toplumlarda erkek kendisinin ve ailesinin şerefini ve namusunu korumak zorunda hissetmektedir. Tezcan'ın çalışmasında yer alan istatistiki verilere göre, mahkûmlara uygulanan bir ankette "İnsanın canı mı, yoksa şerefi mi daha önemli?” sorusuna mahkûmların \%69'u namus ve şerefi; \%16'sı canı önemlidir diye cevap vermiştir. "İnsan neden katil olur?" sorusuna "Yakınlarının namus ve şerefini korumak için." cevabını verenlerin oranı \%52 olarak bulunmuştur. Koçtürk'e göre ${ }^{26}$ erkekleri kadınların "namus"unu korumak ile sorumlu tutan namus etiğinin altında yatan inanç, ataerkil sistem içinde iffetlerini korumaları konusunda kadınlara güvenilemeyeceği inancıdır. Zeybekoğlu’na ${ }^{27}$ göre, toplumsal cinsiyete dayalı rollerin ve sorumlulukların yapısı, kadınları olumsuz etkileyip dezavantajlı konuma getirirken, erkeği yaşamın farklı alanlarında imtiyazlı konuma getirmektedir. Benzer şekilde, çifte cinsel ahlak standardı da, toplumsal cinsiyet eşitsizliğini yansıtan ve bir yandan da pekiştiren bir olgudur. Çifte cinsel ahlak standardı, önüne gelenle düşüp kalkma ya da cinsel olarak fazla öne çıkan davranışların erkeklerden beklenmesi veya takdir edilmesine karşın kadınlarda sapkınlık olarak görülmesine ilişkindir. Romanda tecavüz eden amca ile hiç ilgilenilmemesi, kadının tecavüz mağduru olarak değil, ailesini küçük düşürmüş biri olarak algılanması bu çifte cinsel ahlak standardını yansıtmaktadır:

İnsan değildi onlar, başka bir şeydiler. Önünde duran da artık çocukluğunu bildiği küçük kız değildi, bir kadındı, hem de lekelenmiş, boğazına kadar günaha batmış, ailesinin yüzünü yere indirmiş, isimlerini beş paralık etmiş, babasını ve amcasını rezil etmiş bir kadın. Aile bu utançla yaşayamazdı ve asırlardan beri bu işin kuralı konmuş, cezası belirlenmişti.

Romanda da görüldüğü gibi, Türkiye’de toplumca benimsenen değerlerden sapmalar söz konusu olduğunda töre, sert ve acımasız yaptırımlar öngörebilir. ${ }^{28}$ Namus cina-

22 Işık ve Sakallı Uğurlu, "Namusa ve Namus Adına Kadına Uygulanan Şiddete İlişkin Tutumlar Ölçekleri” 17. 23 Nüfus Bilim Derneği, “Türkiyede Namus Cinayetlerinin Dinamikleri”, haz., Filiz Kardam (Ankara: Nüfus Bilim Yayınları, 2005): 16.

24 Bilgili ve Vural, "Kadına Yönelik Şiddetin En Ağır Biçimi: Namus Cinayetleri”, 66.

25 Mahmut Tezcan, Türkiye’de Töre (Namus) Cinayetleri: Sosyo-Kültürel Antropolojik Yaklaşım, (Ankara: Bahar Kitabevi, 2003), 10.

26 Tahire Koçtürk, “A Matter of Honour: Experiences of Turkish Women Immigrants”, Feminist Review, 46 (Spring, 1994): 99.

27 Özge Zeybekoğlu, Toplumsal Cinsiyet Bağlamında Erkeklik Olgusu (Ankara: Eğiten Kitap, 2013), 18

28 Mustafa Şeker, İbrahim Toruk ve Rengim Sine, “Töre Cinayetlerinin Türk Medyasında Sunumu: Mardin 
yetlerinin sadece kırsal kesimle sınırlı kalmayıp, göçler, aşırı kentleşme, köy kent arasındaki yoğun toplumsal hareketlilik ve artan iletişim yoluyla büyük kentlere hatta Almanya, Hollanda, Avustralya gibi ülkelere de taşınmış olması da söz konusudur. ${ }^{29}$ Göçlerle birlikte şehirlere de taşınan namus cinayetlerinin yalnızca işleniş biçimleri farklılık gösterebilmektedir. Romanda bu farklılığa ilişkin de anlamlı bir tespit yapılmıştır:

Muhtarın oğluyla kavaklikta konuşurken görüldü diye aile meclisi kararıyla boğulan kızlar ya da intihara zorlananlar. Ama son yıllardaki göç dalgası, Doğu’nun bütün kadim gelenekleriyle birlikte töre cinayetlerini de İstanbul'a taşımıştı. Genç kızlar ya viyadüklerden atılıyor ya kurşunlanıyor ya da iple boğuluyorlardı. Hem en yakın akrabaları, kardeşleri tarafindan. Böyle haberler okuduğu zaman en çok kızların annelerini merak ediyordu. Bir kadın doğurup emzirdiği kızını ölümüne nasıl razı olabiliyordu acaba? Yoksa çaresiz mi kalıyorlard??

Bu soru anlamlıdır çünkü; kadının uğradığı şiddete kadının sessiz kalışını düşündürmektedir. Serdar Tekeli’ye ${ }^{30}$ göre kadına yönelik geleneksel mitlerin yaygınlığı, kadına yönelik şiddetin yaygınlığı ile paraleldir. Toplumda şiddetle paylaşılan cinsiyetçi tutumlar, dezavantajlı konumda bulunan kadına yönelik önyargılar üzerinde oldukça etkilidir. Bugün tecavüze uğrayan bir kadın, kısa etek giydiği için suçlanmakta, işinden, yaşadığı çevreden uzaklaşmak zorunda kalmakta, bir ağabey kaçırılarak tecavüz edilen kardeşini öldürürken "namus" bahanesi arkasına saklanmakta ve şerefini koruduğunu ileri sürmekte, geleneksel rolüne aykırı davrandığı düşünülen boşanan kadına ev kiralanmamakta ve kadınlar bu gibi çeşitli gerekçelerle gerek fiziksel şiddete maruz kalmak suretiyle gerek toplumsal dışlanmayla karşı karşıya bırakılarak mağdur edilmektedirler. Toplumun değer yargıları çerçevesinde şekillenen toplumsal cinsiyet kodları, bireyleri baştan ayağa sarıp sarmalamakta ve bu motifler kitle iletişim araçları, eğitim kitapları ve grupsal baskılarla perçinlenmektedir.

Erkek egemen toplumlarda, kadınlar sadece namus kavramı üzerinden ikincil konuma itilmemektedir. Çoğu kez eril iktidarı korumak için erkeğin kadından üstün olduğu vurgulanır. Kadının geri planda, ikincil statüde ve eksik olduğu algisı söz konusudur. Atabek'e ${ }^{31}$ göre, Türkiye toplumunda kız çocuğun doğumu ile erkek çocuğun doğumuna verilen tepkiler de farklıdır. Erkek çocuk doğduğunda sevinmenin temelinde ekonomik gerekçeler de yatmaktadır. "Erkek adamın erkek çocuğu olur" gibi atasözleri, oğullarının olmasının babaların koltuklarını kabarttığını göstermektedir. Bu gündelik, sıradan görünüşlü davranışlar bile "erkeklik ideolojisinin" yaşadığını göstermektedir. Daha bebek doğmadan kendini gösteren bu

Katliamı", Global Media Journal, 3 (2013): 168.

29 Mahmut Tezcan, Ülkemizde aile içi töre ya da namus cinayetleri. Töre cinayetleri, T.C. Başbakanlık Kadın Statüsü ve Sorunları Genel Müdürlügü̈: KSSGM. (Ankara: Beyda Basımevi Ofset, 1999), 22.

30 Esra Serdar Tekeli, "Toplumsal Cinsiyet Çerçevesinde Kadın Mağduriyeti” (yüksek lisans tezi, Ankara Polis Akademisi Suç Araştırmaları Anabilim Dalı, 2011), 80.

31 Erdal Atebek, Kışkırtılmış Erkeklik Bastırılmış Kadınlık (İstanbul: Cumhuriyet Kitapları, 2015), 22. 
“ayrımcı davranış” artık bebeklikten başlayıp hayat boyunca sürer. Örneğin yaşamın ilk yıllarında daha çok erkek bebeklerin fotoğrafları çekilir; bu fotoğraflarda sırt üstü yatmış ve çıplak pozları vardır. Bu bebek fotoğrafı değil, aslında "erkeklik" fotoğrafidir.

Daha bebeklikten itibaren başlayan bu ayrımcı davranışlar, ilerleyen yıllarda birçok alanda kendini gösterebilmektedir. Çocukların kıyafetlerinin renk seçimini veya oyuncaklarının türünü belirleyen anne-babalar çocuğun hayatı boyunca içine hapsolacağı bir cinsiyet kalıbını farkında olmadan inşa ederler. Oluşturulan bu kalıplar yalnızca giyim kuşam ve oyuncaklarla sınırlı kalmaz. Erkekle kadın arasında bulunduğuna inanılan farklılıklarla ilgili kalıp yargılar da çocuğa aktarılır. Erkek çocuklara tanınan pek çok hak ve özgürlükten kız çocuklarının mahrum bırakılması da kız-erkek çocuk arasındaki ayrımı güçlendirmektedir. Kız çocuklar toplumumuzda pek çok kesim tarafından ikincil statüde kabul edilebilmektedir. Kimi bölgelerde evlat sayısı sadece erkek evlat sayısı ile ifade edilebilmektedir. Kimi bölgelerde de kız evlatlar açıkça erkek evlatlardan daha az sevgi gösterisine maruz kalmaktadır. Türkiye’de sahil şeridine ait toprakların bir zamanlar değersiz ve tarıma elverişli olmadığ için kız evlatlara bırakıldığı rivayet edilir. Dolayısıyla kadın olmak, pek çok anlamda ikinci sınıf ve daha az değerli olarak kabul edilmektir; erkeğe ait alanlarda var olamamaktır. Bu kimi zaman aklın, düşünmenin ön plana çıktığı alanların erkeğe teslim edilmesi anlamina da gelebilmektedir.

Zeybekoğlu ${ }^{32}$ cinsiyetçi ideolojiye göre kadın olmanın, yaşamın her alanında erkeğe göre tanımlanmak, erkeğe özgü sayılan davranışlarda bulunmamak, duygu ve düşüncelerini erkeğe göre belirlemek gibi anlamlar taşıdığını belirtmektedir. Buna göre, kadın edilgen, duygusallığından dolayı akılcı davranamayan, cesaretsiz ve var oluşu ailesinin sınırları içinde meşru görülen bir varlıktır. Romanda, Meryem’in iç konuşmaları kendini eksik, yetersiz ve değersiz hissettiğini göstermektedir. Meryem'in sözleri aracılığıyla yazar, Türkiye’de kadınların bir kısmının kendini var olmakla bile suç işlemiş gibi hissettiğini güçlü bir biçimde anlatmaktadır:

Kadınlığa adım attı̆̆ı gün, neden annesi olmadığını anlamıştı artık. O da ceza görmüş olmalıydı ki bebek doğururken ölmüş̧ı̈̈. Eğer Allah onu cezalandırmasa kadın değil erkek olarak yaratırdi; böylece doğum yapmaz ve ölmezdi. Şimdi kendisi de kadın olmanın cezasını çekiyordu işte. Kadınların başına bu işleri açan, onları bu hallere düşüren hep o günah yerleriydi. Meryem bunu biliyor$d u$. Orası yüzünden günaha giriyor, orası yüzünden cezalandırllıordu. Günah yeri olmasın diye öyle çok dua etmişti ki, sayısını bilmiyordu artık. Bir sabah kalktığında orası kaybolmuş, günah yeri kapanıp gitmiş olsun diye durmadan yakarmış ama sabah baktığında, o çirkin şeyin yerli yerinde durduğunu görünce umutsuzluk kaplamıştı içini. Henüz kadın olmadığı günlerin mutluluğunu düşündü. İlkokula gittiği, küçük bir kız çocuğu olarak sokaklarda özgürce koşup oynadığı, Cemal ve Memo abilerle çember çevirdiği günleri. 
Kadının romanda bahsedildiği gibi kendini daha değersiz ve yetersiz görüşü, kadına toplumca aşılanan bir görüştür. Atabek ${ }^{33}$, kadınlık ve erkekliğe verilen değer fark1nı bir örnekle açıklamaktadır. Karşılaştığı engellemelerden yılan bir kadının "keşke erkek olsaydım" dediği görülür ancak bir erkeğin "keşke kadın olsaydım” dediğine rastlanmaz. Bu davranışın temel nedeni erkekliğin yüceltilmesi ve kadınlığın aşağılanmasıdır. Toplumsal öğreti, sadece iki durumda kadının bu aşağılamadan kurtulabileceğini göstermektedir; bir erkeğin eşi olmak(eşi olunan erkeğin toplumsal değerine bağlı olarak) ve anne olmak. Bu iki durum da kadının birey olarak değeriyle ilişkili değildir. Ökten ${ }^{34}$ tarafından Güneydoğu Anadolu Bölgesinde yapılmış bir çalışmaya göre, çocuk doğurmak, gebeliği önleme ve kürtajla ilgili egemen anlayış, kadınların doğurganlığını, bedenini ve cinselliğini kontrol etmesi noktasında engelleyici mekanizmalar olarak değerlendirilmektedir. Fakat bu anlayışın da parçası olduğu genel sosyolojik ortam göz önüne alındığında; bölgede çocuk doğurmak, çok çocuk doğurmak ve özellikle erkek çocuk doğurmanın belirgin bir şekilde kadının yararına olduğu anlaşılmaktadır. Aslında dünyaya çocuk getirmenin, yalnızca bölgede değil tüm Türkiye'de hem erkeklerin hem de kadınların birincil kaygılarını oluşturduğu söylenebilir. Erkekler hayat kıvılcımının taşıyıcısı, soyun devam ettiricisi olarak değerlendirildiğinde, soyun devamı babadan oğula geçtiği için erkek evlat soyun bir parçası, devam ettiricisidir. Dolayısıyla, bölgede evli olmayan evli olsa da erkek çocuk sahibi olmayanlar, "ocakları"nı sürdürecek kimse olmadığı için "körocak” olarak değerlendirilir. Bu anlamda bölgede "çocuk" sözcügüüün, hem çocuk hem de oğlan çocuk anlamında kullanılması, bu durumu açıklayıcı, yaygın olarak bilinen bir gerçektir. Bu açıdan bakıldığında, toplumsal olarak doğurganlığın kadının statüsünü arttırması için çocuğun cinsiyeti de önemlidir.

Dünyaya çocuk getiren annenin statüsünün yükselmesi yalnızca Güneydoğu Anadolu bölgesine has bir durum değildir. Demez ${ }^{35}$ yıllarca ataerkil baskılar sonucu bunalan kadınların gelecek hayalleri arasında erkek çocuk doğurmanın ve onu kendisine bağlı bir evlat olarak yetiştirmenin yattığını belirtir. Oğlunun büyüyüp evlenmesi ile yıllarca çektiği acıların karşılığı olarak kendi gelini üzerinde egemenlik kuracaktır. Bu durum ataerkilliğin yoğun yaşandığı ailelerde bizzat kadın tarafından ataerkilliğin yeniden üretilmesi olarak değerlendirilir. Bu yeniden üretim, kadının konumunun düzenlenmesi için harcanan çabaların önünü tıkamaktadır. Sancar ve diğerlerine $^{36}$ göre annelik, kadınları en fazla güçlendiren deneyimlerden biridir; çünkü kendilerini var edebilecekleri meşru bir alan açar. Bu varlık son derece sıkı bir biçimde belirlenmiş, sınırları çizilmiş olsa da, yine de, güçlendirici bir etkisi vardır. Romanda da, anneliğin Meryem'in üvey annesine verdiği güç tasvir edilmektedir:

Düşündükçe, Döne’nin yılan gülümsemesiyle bir araya gelen konuşmasındaki dehşetli gizli anlamı daha bir derinden kavrıyordu. Döne babasıyla da konuş-

33 Atebek, Kışkırtılıış Erkeklik Bastırılmış Kadınlık, 35.

34 Şevket Ökten, "Toplumsal Cinsiyet ve İktidar: Güneydoğu Anadolu Bölgesi’nin Toplumsal Cinsiyet Düzeni” Uluslararası Sosyal Araştırmalar Dergisi 2/8 (2009): 306.

35 Demez, Kabadayıdan Sanal Delikanlıya Değişen Erkek Imgesi, 36.

36 Serpil Sancar, Selma Acuner, İlknur Üstün, Aksu Bora, "Cinsiyet Eşitsizliği Bir Kadın Sorunu Değil, Toplumun Sorunudur”, UNDP-Kalkınma ve Demokratikleşme Projelerinde Cinsiyet Eşitliği Hedefinin Gözetilmesi Eğitimi 2005-2006, (UNDP, İstanbul 2006), 21. 
muş olmalıydı bu işi. Çünkü genç bir kadın ve yeni gelin olarak babası üzerindeki etkisi çok büyüktü. Üstelik kısır çıkan ikinci karısından sonra, ona iki de evlat vermişti.

Elbette Türkiyede kadının erkek karşısındaki konumu bu şekilde, yalnızca annelik ile değişmemektedir. Kadının statüsünü artıran konulardan biri de yaşlanmasıdır. Geniş bir kesim için otorite yaşlılık veya erkeklik anlamını taşımaktadır. Mardin $(2008)^{37} \mathrm{de}$, "geleneksel olarak Türkiye yaşlıların otoritesine dayanan bir toplum olmuştur" demektedir. Ökten (2009) ${ }^{38}$ Güneydoğu Anadolu’da otoritenin daha çok yaş ve cinsiyet gibi fizyolojik niteliklerden kaynaklandığını ileri sürmektedir. Diğer bir ifadeyle, otoritenin yaşlılar ve erkeklerde toplandığı geleneksel ailede baba ya da kocanın sözü geçerli olmaktadır.

Türkiye'de yaşlı bir kadın, genç kadınların uymaları beklenen kimi toplumsal cinsiyet kalıp yargılarından muaf olabilmektedir. Bu durumda temelde, yaşlanan kadının cinselliğini yitirmiş olduğu anlayışının da yattığı düşünülmektedir. Kadın bu hali ile korunmaya muhtaç veya namusu tehdit eden bir konumda olmaktan çıkmaktadır. Romanda Gülizar ebenin erkeklerle konuşmaktaki cesareti bu durumu örneklemektedir:

Çünkü Gülizar Ebe, evin reisi olan amcaya bu işi yapanı bulup Meryem»le evlendirmenin en iyi çözüm olduğunu anlatıp diler dökmüştü. Yaşl bir kadın olduğu için erkeklerle çatır çatır konuşabiliyordu. Ama asık suratl adam, "Ailemize bir piç girmesiyle, bir ırz düşman girmesi arasında hiçbir fark yoktur!" diye kestirip atmıştı. "İkisi de olmaz!"

Kadının gücünün kabul edildiği bu ender durumlar dışında, erkeğin aslında kadının gücünden korktuğunu düşündüren yaklaşımlar da söz konusudur. Akçay'a ${ }^{39}$ göre, erkekler kadınlar karşısında korkularıyla baş edebilmek için onları ya aşağılamış ya da yüceltmiş; ama oldukları gibi görme konusunda pek mesafe kat edememiş ve bu kaygıyla başa çıkabilmek için insan’ı (aklı) erkekle özdeşleştirip uygarlık diye bir şey icat etmişlerdir. "kadın denize benzer", "kadın bir muammadır" "kadın denen meçhul" gibi sözler erkeklere aittir ve kendi cinselliklerinin apaçı sınırlılı̆̆ına karşın, kadın cinselliğinin niteliksel farklılığı karşısındaki korkularını ifade eder. Bu nedenlerle, cinselliği olan kadın bir arzu ama aynı zamanda bir tehdit nesnesidir. Ayaklarının altına cennetin serilmesi için kadınların tehdit olmaktan çıkmaları yani arzudan muaf hale gelmeleri gerekir. Romanda İrfan Kurudal'ın erkeklerle ilgili gözlemi, sözü edilen korkuyu yansıtmaktadır:

Oysa İrfan, Türk erkeği denilen türün hayatı boyunca devam eden kadına tapma ve kadın düşmanlığı çelişkisinin, küçük yaşta geçirilen bu sünnet travmasına bağh olduğunu düşünüyordu.

37 Şerif Mardin, Türk Modernleşmesi: Makaleler 4 (İstanbul: İletişim Yayınları, 1991), 281.

38 Ökten, “Toplumsal Cinsiyet ve İktidar: Güneydoğu Anadolu Bölgesi’nin Toplumsal Cinsiyet Düzeni”, 309.

39 A. Adnan Akçay, "Arzu, Cinsellik ve Erkekler”, Erkekler, haz., Ayşe Akaltun (İstanbul: Notabene Yayınları, 2015), 57. 
Romanda olduğu gibi, günlük yaşamda da sözü edilen korkunun temelde cinsellikle ilişkilendirildiği anlaşılmaktadır. Demren'e ${ }^{40}$ göre Ortadoğu'da kadınlar, cinselliklerini kontrol edebilen, hâkim olabilen özneler değil, erkeklerin kontrol etmesi gerektiği düşünülen "nesneler” olarak görülmektedir ve buna göre kadınların cinselliğinin sınırlanması gerekir. Kadınlar kocalarını ve çocuklarını kendilerine bağlayabilmek için “doğaüstü güçlerle işbirliği” yapabilirler. Erkekler "denetimli” ve "akılcı”yken, kadınlar "erotik" ve "akıl dışı”dırlar; onun için kadın ve aşk, erkeğin Allah'a olan bağlılı̆̆ı ve yapması gereken işler için birer tehdit olarak görülür. Hiyerarşik ataerkil ilişkilerle, kadın ve erkek arasındaki duygusal ve aşka bağlı ilişsiler arasında ciddi bir gerilim vardır. Cinsellik ancak ataerkilliğin belirlediği şekilde ve sınırlar içerisinde var olabilir, yoksa kendi akışı içerisine bırakılır, aşkla ve sevgiyle yaşanılırsa bu ataerkillik için yıkıcı bir nitelik olarak görülür.

Marshall'a ${ }^{41}$ göre, erkeğin yıkıcı yapısının kadına yansıtılması söz konusudur. Bu durum en belirgin olarak, erkeğin kadına hükmetmesi gerektiğini, aksi takdirde kadının insanlık için büyük kötülüklere yol açacağı anlayışında görülür. Ortaçağda, şehvetli diye nitelendirilen davranışları olan kadınların şeytana yardımcı cadılar olduğuna inanılmıştır. Bu sebeple tehlikeli cadıların öldürülmesi gerektiğine inanmışlardır. Erkek kendi cinsel dürtüsünü kontrol etmek yerine, cinsel ilgi duyduğu kadını öldürmeyi seçmiştir. Tıpkı cadılar gibi fahişeler de tarih boyunca aşağılanmıştır. Bir fahişe dövülerek öldürülse çok az tepki görülür. İlginç olan şu ki, erkeğin geçici heyecanı için kendi bedenini satan kadın aşağılanırken, bunu talep edip para ödeyen erkek normal kabul edilir. Buna çarpıcı bir örnek, Birinci Dünya Savaşı sırasında iktidarda olan erkeklerden sırlar almak için onlarla birlikte olan Mata Hari adlı casus kadındır. Ona sırları veren erkek generaller yerine, Mata Hari idamla cezalandırılmıştır.

Marshall'a göre erkek kadının biyolojik olarak aşağı olduğunu ve sağlıklı akıl yürütme yeteneği bulunmadığını söyleyerek kendi gücünün baskın olduğu toplumlar yaratmasını meşru kılmak için her zaman savunma mekanizmalarından mantığa bürümeyi (rasyonalize etme) kullanmıştır. Mantığa bürüme erkeğin kadına hükmetmesini de haklı göstermesine yaramaktadır. Mantığa bürüme, erkeğin kadını kontrol altına alma amacıyla oluşturduğu kültürel ve dinsel yapılara da yerleşmiştir. Marshall’a göre, erkek, vücudunun bazı bölümleri açık olan kadının yanında cinsel dürtülerini kontrol edemediğini sosyal gelenekler ve dinsel dogmalar aracılığıyla kabul ettirmiştir. Erkek bu konuda zayıflı̆ııın sorumluluğunu kabul etmez; bu sorumluluğu kadına yüklemeye çalışıp onu bedenini örtmeye zorlar. Doksanlarda SSCB’nin güneyindeki ülkelerden birinde, Müslüman erkekler makyaj yapan kadınların yüzlerine bıçak vb aletlerle saldırmışlar; çekici olan yüzleri çirkinleştirmişlerdir. Bu zulmün bahanesi olarak Tanrı̉nın iradesini uyguladıkları biçiminde bir mantığa bürümeye başvurmuşlardır. Romanda Meryem’in amcasının yeğenine tecavüz etmesine rağmen, kadınları günahkâr olarak görmesi ve kadınlığı aşağılaması sözü edilen savunma mekanizmalarını yansıtır gibi görünmektedir:

40 Çağdaş Demren, “Ortadoğu'da Ataerkillik ve Erkeklik İlişkileri”, C.Ü. Sosyal Bilimler Dergisi 32/2 (Aralık 2008): 325.

41 Tim Marshall, Hükmeden Erkek Boyun Eğen Kadın, (İstanbul: Altın Kitaplar Yayınevi, 1997), 105. 
Amcasına göre insanların hepsi günahkârdı ama kadınlar iyice cehennemlikti. Bu dünyaya kadın olarak gelmek, cezalandırılmak için yeterliydi. Kadın şeytandi, pisti, tehlikeliydi, Havva anamız gibi, adamların başını derde sokardı; karnından sıpayı, sırtından sopayı eksik etmemek gerekirdi; çünkü onlar, insan soyunun yüz karasıyd. Meryem bunları duya duya büyüdüğ̈̈ için dişi olmaktan nefret eder ve, "Allahım, beni niye kadın olarak yarattın?" diyerek kendisini boğazına kadar günaha sokacak sorular sorardı. Kolları bacakları sopa gibi kuru, zayıf bir çocukken her şey daha kolaydı.

Ne zaman ki göğsünde iki tomurcuk belirip gövdesi yuvarlak hatlar edinmeye, bacaklarının arası kanlanmaya başladı, o zaman kendisinin hiçbir zaman Cemal ve Memo gibi olamayacağını kavradı. Onlar insandı, kendisi ise suçlu. Saklanması, örtünmesi, hizmet etmesi, ceza görmesi gerekiyordu; bunun başka türlü olması mümkün değildi. Dünya 'kadın' denilen pis mahlûklar yüzünden felaketlere sürüklenmişti.

Romanda görüldüğü gibi, çocukluktan itibaren kadının aşağılanması erkek çocuklara da bir mesaj vermekte; erkekleri üstün ve egemen olduklarına inandırmaktadır. Erkeklere, ataerkil toplum içinde kendi cinsiyet rollerinin egemen olması gerektiği yönünde yapılan toplumsal baskı, kadın düşmanlığını anlamına gelen mizojini kavramını da beraberinde getirmektedir ${ }^{42}$. Popüler kültür unsurları tarafından yaratılan ve topluma yansıtılan mizojini, kadınlara karşı var olan düşmanlık, nefret, kadınların aşağılanması veya cinsiyet özelliklerinden dolayı küçümsenmesi, cinsel bir obje olarak görülmesi (nesneleştirilmesi), kadınlara karşı her türlü şiddetin meşrulaşt1rılması, kadın bedeninin metalaştırılması olarak karşımıza çıkmaktadır. ${ }^{43}$ Romanda, Meryem'in amcasının ve Cemal'in iç sesleri, kadınlara hem tehlikeli ve şeytani yönler yüklediklerini, hem de onları aşağıladıklarını ve cinsiyet özelliklerinden dolayı zayıf gördüklerini göstermektedir:

İnsanın o azaplara duçar olmasına gerek yoktu, dinlemesi yeterliydi kanının donması ve kadın denen aldatıcı, ifsat edici, insanın kanma girici, şeytanın, yeryüzünde iğvasına araç olarak kullandiğı o zayıf mahlûkun ne işler çevirebileceğini anlaması için.

Bugüne kadar eli, o zavall erkek eli, Emine'nin eline bile değmemişti. Bu yüzden onun vücuduyla arasına dikilen her engeli bir an önce aşıp yatağa girebilmek için inanılmaz derecede güçlü bir arzu duyuyordu. Askerlik bitince bu olanağa kavuşacağını sanmıştı ama şimdi de Emine ile arasına bu sümüklü kız dikilmişti. Askerde iken arkadaşlarının elinde gördüğ̈̈ dergiler de onu böyle alır yerden yere vururdu işte. Kadın denilen içine şeytan girmiş yaratı̆̆ın erkeği ifsad ettiği o kadar belliydi ki.

Romanda olduğu gibi, tarih boyunca ve farklı kültürlerde kadının negatif simgeler ile özdeşleştirildiği anlaşılmaktadır. Eski Çin felsefesinde Yin ve Yang, erkek çifte

42 Philip Etyang, Amateshe Kisa ve Makokha Jks, Misogyny in Urban Fiction : A Study of Selected Texts by Meja Mwang (United States: Scholars' Press, 2015), 22.

43 Veysi Baydar, "Popüler Kültürde Mizojini”, Turkish Studies 8/151 (Güz 2013): 153. 
standartlı bir felsefeyi yansıtmaktadır. Buna göre kadının evrende negatif bir gücü, erkeğinse pozitif bir gücü temsil ettiği kabul edilir. Benzer şekilde, Yunan felsefesinde, Pisagor’un “düzeni, aydınlığı ve erkeği yaratan iyi bir ilke; kargaşayı, karanlığı ve kadını yaratan kötü bir ilke olduğu” yönündeki sözleri yine kadının negatif bir güçle ilişkilendirilmesine örnek oluşturmaktadır. ${ }^{44}$

Profesör, "Size hak veriyorum ama," dedi, "Batı kültüründe de kadın suçlu ve günahkâr!" "Nasıl?” "Evil kelimesini düşünün." "Evet!” "Sizce bu kelime Eve'den yani Havva'dan gelmiyor mu?" Büyükelçi kaşlarını çatıp bir an düşündü ve, "Galiba haklısınız aziz Profesör," dedi. "Eve, evil; yani ilk günah. Çok doğru! Bravo! Hiç olmazsa bizde Havva adından türetilmiş kötülük anlamında kelime yok."

Romanda entelektüel açıdan üst kesimi temsil eden iki karakterin konuşmaları kadınlarla ilgili kalıp yargıların aslında sadece okumamış veya cahil diye nitelendirilen bir kesime ait olmadığını göstermektedir. Birçok toplumda erkekler daha güçlü benlikleri yansıtan kalıp yargılarla (güçlü, bağımsız....), kadınlar ise daha zayıf benlikleri yansıtan kalıp yargılarla (bağımlı, pasif...) tanımlanmaktadır. Kadın cinsiyetine ilişkin bu olumsuz kalıp yargılar, kadının politik, ekonomik ve sosyal alanda erkeğe göre daha düşük konumda kalmasına neden olmaktadır. ${ }^{45}$ Ataerkil değerlerin egemen olduğu Türk toplumundaki geleneksel erkeklik algısı, erkeğin her zaman başarılı, güçlü, iktidar sahibi olması, her şeye çözüm getirebilmesi, duygularını asla belli etmemesi, evin geçimini sağlaması ve belki de en önemlisi, her zaman her konuda kadından üstün olması gerektiği şeklindedir (Zeybekoğlu, 2010). ${ }^{46}$

Erkeklere, kadına "erkekçe” arzu duyabilecekleri ama 'insanca' ihtiyaç duyamayacakları düşüncesi, ataerkil toplum ve kültür tarafından yoğun bir şekilde empoze edilmektedir. Çünkü erkeğin bir insana özellikle de bir kadına, yaşamsal, üretimsel ve insancıl ihtiyaç duyması ataerkillik tarafından "erkeğin zayıflığı” olarak damgalanmıştır. Kadın ve erkek arasındaki duygusal ilişki, toplum tarafından "kadının erkeğe bağımlılığı”, "ikincilliği”, "erkeğin kadına başat olması ve sınırlaması gerektiği”" söylemleriyle farklı bir boyuta taşınmıştır. ${ }^{47}$ Romandan bazı kesitler kadının erkeğe tabi hale getirildiği ve erkeğin sadece erkek oluşu ile yüceltildiği gerçeğini yansıtmaktadir:

Akşam namazından sonra yere kurulan ve kadınların hizmet ettiği sofrada sadece erkekler yemek yiyor, bu arada kadınlar ayakta bekliyor, onların yemeği bittikten sonra sofradan arta kalanları götürdükleri mutfakta yemeye başlyyorlard 1 .

Çok dertli bir hali vardi; o kadar dertli ki neresinden başlayayım, hangi birini anlatayım der gibi bir umursamazlı̆̆a vurmuş, vaktinden önce yaşlanmaya

44 Marshall, Hükmeden Erkek Boyun Eğen Kadın, 101.

45 Nuray Sakallı-Uğurlu, "Cinsiyetçilik: Kadınlara ve Erkeklere İlişkin Tutumlar ve Çelişik Duygulu Cinsiyetçilik”, Türk Psikoloji Yazıları 6/11 (2003): 4.

46 Özge Zeybekoğlu, “Toplumsal Cinsiyet Rolleri Bağlamında Türk Toplumunun Erkeklik Algısı”. ETHOS: Felsefe ve Toplumsal Bilimlerde Diyaloglar 3 (Kış 2010): 7.

47 Demren, “Ortadoğu’da Ataerkillik ve Erkeklik İlişkileri”, 325. 
başlamış bir kadın. Eve dışarıdaki çeşmeden su taşıyor, üç çocuğun bakımıyla uğraşlyor, haftanin dört günü temizliğe gidiyor ve Meryem>in ertesi gün anlayacağı gibi geceleri i de Yakupıun altında mesai yapıyordu.

Sonra kadın olmanın zorluklarından, her kadının geçtiği dikenli yollardan, zaten kadersiz yaratıldiklarından dem vurdu ve arada bir, "Kadınlık batsin!" diye tekrarlayan uzun bir ağıda başladı. "Bak," dedi, "adını taşıdı̆̆ın mübarek Meryem Ana bile ne çileler çekti."

Romanda, toplumun bir kesimi ile ilgili katı bir erkeklik vurgusunun resmedildiği de görülmektedir. Temelde erkeğin kadından ayrı, daha üstün ve yüce oluşuna dair algı ele alınmaktadır. Türkiye'de erkek olmanın temel anlamı, kadın gibi olmamaktır. Kadın gibi gülmemek, yürümemek, giyinmemek, kadının yaptığı işleri yapmamak, yapılıyorsa bile bunları makul sınırlarda tutmak, erkekliğin tanımının yapılmasını kolaylaştırmaktadır. Tersinden bakarsak, Türkiyede sert, güçlü ve yetke sahibi olmak bir bakıma erkek olmayı vurgulamaktadır. Asıl ilginç olan ise, bu durumun kadınlar tarafından da onaylanıyor olmasıdır. ${ }^{48}$ Bozok' ${ }^{49}$ göre, erkekler, erkeklerin dünyasında yer alabilmek, "erkek adam" olabilmek adına duygularına yabancılaşırlar, bitmek bilmez cinsel tatminsizliklerle boğuşurlar, çalışma yaşamında sürekli başarılı olma baskısı yaşarlar, kurdukları kavga ve savaş dolu dünyada yaralanırlar. Buna göre, erkeklik rollerinden farklı davranmak dışlayıcı ve küçümseyici tavırlarla karşılaşmak için yeterlidir. Erkeklik, Bozok tarafından kendi kendini yiyen bir mitolojik yaratığa (Ourobos) benzetilmektedir; buna göre, erkeklik sürekli yeniden üretilmeyi gerektiren bir toplumsal inşadır. Bozok’a göre, erkeklikler bireysel yollardan, erkeklerin kendileri tarafından her gün tekrar tekrar inşa edilirler. Bu sürekli inşalara katılma ihmal edildiği ya da ona itiraz edildiği takdirde erkek egemenliğini taşıyan ve icra eden diğer erkekler tarafından erkekliğine meydan okumalarla, erkekliğin elinden alınması, erkekliğinden olma, kadınlaşma, eşcinsellik gibi tehdit ve korkutmalarla karşılaşılır. Erkek egemenliği erkeklere gündelik yaşamlarında çeşit çeşit kolaylıklar, avantajlar ve ayrıcalıklar sağlarken, erkekliğe yönelik itiraz erkekler dünyasının dışına atılma tehditleriyle karşı karşıya kalır.

Akaltun'a ${ }^{50}$ göre, toplum kadınlardan itaat eden, sesini çıkartmayan, verilen rolleri kabul eden bireyler olmalarını beklerken, erkeklerden de sert, iktidarın dilini kullanan bireyler olmalarını beklemektedir. Erkeklerin sünnetle başlayıp askerlikle pekiştirilen "sert erkek" kavramının erkeklerin hayatına ne kadar işlediği ve yüklenen rollerden memnun olup olmadıkları sorgulanması gereken bir konudur. Barutçu'nun ${ }^{51}$ belirttiği üzere bir erkek, toplumda kendisinden beklenen tutum ve davranışları gerçekleştirerek erkekliğini kanıtlamaktadır. Ondan beklenen performansı gerçekleştiremeyen erkek, toplumsal cinsiyet normlarına uyamamaktan do-

48 N. Aysun Yüksel, Tarkan Yıldız Olgusu (İstanbul: Çivi Yazıları, 2001), 89.

49 Mehmet Bozok, "Profeminizm, Ben ve Kendim", Erkekler, haz., Ayşe Akaltun (İstanbul: Notabene Yayınları, 2015), 33.

50 Ayşe Akaltun, “Fotoğraf Karesi”, Erkekler, haz., Ayşe Akaltun (İstanbul: Notabene Yayınları, 2015), 33.

51 Atilla Barutçu, “Türkiye’de Erkeklik İnşasının Bedensel ve Toplumsal Aşamaları” (yüksek lisans tezi, Ankara Üniversitesi, 2013): 1 . 
layı cezalandırılmaya muhtaçtır. Toplumsal cinsiyet normlarına uymayarak, toplumsal dışlanma başta olmak üzere pek çok manevi ve maddi yaptırımlara maruz kalan erkek, bu yaptırımlardan kaçınmak için erkekliğini ispat etme peşine düşmektedir. Demrene' ${ }^{52}$ göre, ataerkillikte, erkeklik biçimleri ve algılayışları da aynı şekilde kurgulanır. Toplumsal söylemler, bu sosyo-kültürel yapının kurulmasında büyük rol oynarlar. Erkeklere ait kültürel bir "üstünlük" söylemi yaratılır. Erkeğin doğuştan gelen bu "kültürel üstünlügüu” kadına karşı başat olması "hakkını verir". Erkekler "esas" yaratıcıdırlar, ortaya çıkarandırlar ve yıkıcıdırlar, yani erkekler "her şeye kadirdirler". Erkeğin cinsel nitelikleri de "doğal olarak" kadından kuvvetlidir. Erkekler bu "üstünlük"lerini, içerisinde yaşadıkları topluma veya gruba her an "kanttlamak zorundadırlar".

Çocukluktan yetişkinliğe, toplumun beklentileri doğrultusunda davranmak sosyal anlamda desteklenmekte, ödüllendirilmekte; böylece cinsiyete ilişkin kalıp yargılar daha da pekişerek varlığını sürdürmektedir. Dahası bu kalıp yargılar bir kez yerleşti mi değişime oldukça dirençli hale gelmektedir. Dökmen'e ${ }^{53}$ göre toplum hemen hemen her grup için o grubu betimlediği düşünülen özellikleri belirler, kaydeder ve bunu hafızasından silmeye direnç gösterir. Kadın ve erkek grupları için de bu durum böyledir; kadınlar grubunu veya erkekler grubunu oluşturan bireyler bazı özellikleriyle tanımlanır. Bu özellikler grubun tüm üyelerine genellenir. Toplumsal bellekte bulunan bu bilgiler sınanmaksızın her birey için doğru kabul edilir. Bu bilgileri doğrulamayan yaşantılarda şaşırılır ve hatta kimi zaman doğrulamayan bireye öfke duyulur; baskı yapılır. Dökmen'in ifadeleri toplumsal cinsiyetle ilgili kalıp yargıların bireyler üzerinde yarattığı baskıyı düşündürmektedir. Bu baskı uymaya yönelik bir baskıdır. Bireyler bir biçimde var olan kalıp yargılara uymadıklarında öfke veya baskı ile karşılaşabilmektedirler. Taş่'a ${ }^{54}$ göre, toplumsal cinsiyetçi yapıya ters düşmek, kılıbıklık olarak adlandırılır. Kılıbık karısının baskısı alında bulunan erkek demektir. "Kadın gibisin, karı gibisin, yumuşaksın” da denilir. Dozu değişmekle birlikte, cinsiyetçi yapıya ters düşen erkek tepkiyi hak eder; çoğu zaman da bu tepki şakayla dile getirilir. Romanda karısını dövmediği için diğer erkekler tarafından "erkekliği" sorgulanan bir erkeğin durumu, kalıp yargılara uymayan erkeklerin yaşayabileceklerini örneklemektedir:

Kocasının onu öpmeye bile kıyamadığını övünerek anlatıp diğer kadınları pek kızdırmışmış. Orada bulunan tanıdık bir kadın, yeni gelinin bu övünmelerini kendi kocasına anlatmış; o da doğru kahveye gidip adamı bulmuş ve, "Sen ne biçim erkeksin ki karını dövmüyorsun. $O$ da gidip ebe kadinda car car anlatıyor," demiş; hem de herkesin içinde. Bunun üzerine fena halde onuru kırılan adam eve koşup, "Sen benim erkeklik şerefimi iki paralı ettin. Dayağı ye de gör bakalım," diyerek o gün kürtaj olmuş kadının kafasına gözüne Allah yarattı demeden yumruklarını indirmeye başlamış. Taze gelin hem bunları anlatıyor hem de, "O bana kıyamaz ama etrafin aklina uydu!" diyordu hafif bir sesle. "Yoksa bana

52 Demren, “Ortadoğu’da Ataerkillik ve Erkeklik İlişkileri”, 325.

53 Dökmen, Toplumsal Cinsiyet: Sosyal Psikolojik Açıklamalar, 32.

54 Taş, "Mutfak", Erkekler, 66. 
kıyamaz! Beni çok sever. Yalnız kaldığımızda bana hep güvercinim diye seslenir; ama başkaları azdırmış benim kocamı." Meryem içinden düşündü ki bu lafları yüzünden o gece bir daha dayak yiyecek kadın. Sonra, kara çarşaflarmn içinden görünen soluk süt beyazı gevşek gerdanları paluze gibi titreyen kadınları, kendisini de anlayışl gözlerle süzdüklerini gördü. Sanki onlarm kader arkadaşı ya da sırdaşıymış gibi. Sabah kalktığında daha da morarıp neredeyse ciğer rengini almış ve şişmiş yanağını düşündü. Elbette kendisine anlayış gösterecekler ve içlerinden biraz da, oh olsun diyeceklerdi; çünkü zulüm gören, başkasının da zulüm görmesini ister.

Alıntılanan bu durum Türkiye'de sadece dayak yiyen kadının değil, "erkeklik onuru" peşinde, kadını aşağılayan ve ezen pek çok erkeğin dramını anlatmaktadır. Doğu ve güneydoğu bölgesinde yapılan bir araştırmaya göre, bu bölgede yaşayan erkeklerin \% 60’nın, “erkekler kadınlardan daha akıllıdır" ve \% 57'sinin "eşine itaat etmeyen kadını kocasının dövmeye hakkı vardır" yargısını onayladığı belirtilmektedir. ${ }^{55} \mathrm{Er}$ keklik kadın üzerinden sağlanan ve erkek egemen toplum tarafından sağlamlaştırılan bir statüdür. Bir erkeğin erkekliğini ispatlaması ve koruması, erkekliğini kaybetme kaygısıyla daima gerilim taşımaktadır. Durum böyle olunca bu gerilimin kadın üzerindeki toplumsal cinsiyetçi yansımalarını görmek şaşırtıcı olmamaktadır. ${ }^{56}$ Toplumsal cinsiyet olgusu, derinliği sabit olmamakla birlikte dünyanın pek çok ülke ve toplumunda yaşanan bir eşitsizlik sorundur. Toplumsal cinsiyete dayanarak erkek ve kadına biçilen değerler, rol ve kalıplar hiyerarşik olarak erkeğin 'üstte ve önde' bulunması suretiyle ayrıştırıcıdır. Kadın, toplumsal olarak belirlenmiş cinsiyetinden ötürü erkekten ayrı, ötede, öteki olarak tutulmaktadır. Kadınlık, erkeklik statülerinin imkân ve izin verdiği ölçüde erkek egemen kültür tarafından oluşturulmuş bir kurgudur. ${ }^{57}$ Goldberge ${ }^{58}$ göre eski rollerin artık işe yaramadığını bilinçaltı veya bilinçle kavrayan erkek öfke duymaktadır; çünkü oynamayı bildiği roller bunlardır. Kadının daha güçlü olmasa bile onun kadar güçlü olduğunu ve bir erkeğin kadınsız yapabileceğinden çok daha kolay erkeksiz yapabileceğini keşfettiğini bilmektedir. Romanda Cemal'in Meryem’in gücünü keşfetmesi karşısında yaşadığı sıkıntı bu duruma örnek oluşturmaktadır:

Kasabada kendisine hizmet etmekle görevli ve erkeklerin yanında bırak yemek yemeyi, sesini bile duyurmasina izin verilmeyen kiz, Ege klyılarındaki teknede neredeyse kendisine üstünlük taslayacaktı. O hoca da müthiş şımartıyordu kızı. Sulanıyor muydu ne? Cemal, öyle bir şey görürse aile namusunu korumak için Profesörü tekneden suya atmayı bile göze alırd. Böylece her geçen gün onlara karşı biraz daha öfkelenerek ve ayrı oturmaya gayret ederek günlerini yalnız geçirir olmuştu. Bir-iki kere de koylarda denize atlayıp yüzdü. En azından bu alanda Meryeme karşı müthiş bir üstünlüğ̈̈ vardı. Çünkü komando eğitimli

55 Yeter Kitiş ve Sema Şanlığlu Bilgici, "Bir Aile İçi Şiddet Olgusu; Sır Tutma İlkesi ile Şiddeti İhbar Etme Yükümlülüğü Arasındaki Etik İkilem”, Aile ve Toplum 3/11 (2007): 11.

56 Deniz Kandiyoti, Erkeklik Paradoksları: Ayrımcılığın Yaşandığı Toplumlar Üzerine Bazı Düşünceler: Cariyeler, Bacılar, Yurttaşlar, çev. A. Bora ve diğerleri, (İstanbul: Metis Yayınları, 1997), 185.

57 Bingöl, “Toplumsal Cinsiyet Olgusu ve Türkiye'de Kadınlık”, 113.

58 Herb Goldberg, Erkek Olmanın Tehlikeleri, çev., Selçuk Budak (Ankara: Öteki Yayınevi, 1994), 18. 
gövdesinin sudaki yetenekleri, o güne kadar sadece ayaklarını suya sokmuş kıza göre tartışılmaz üstünlükteydi.

Cemal'in kendi üstünlüğünü Meryem’e kanttlamaya ihtiyaç duyan hali, temelde erkeğin üstün olmaya çabalaması ile ilgili baskıyı yaşamın her alanında hissettiğini gözler önüne sermektedir. Barutçu ${ }^{59}$, Türkiyede bir erkeğin erkeklik inşasını başarılı bir şekilde tamamlayabilmesi için gereken mevcut bir takım bedensel ve toplumsal olguların norm haline geldiğini belirtmektedir. Buna göre, toplumun erkeklerden beklediği çeşitli roller, onların ya toplumun üst tabakalarında yer almalarına ya da toplumun derinlerine itilmelerine neden olmaktadır. Toplumsal dönüşümlerle bazen gücünü yitiren, bazen gücüne güç katan bu normlar, toplumsal cinsiyet rolleri düşünüldüğünde, erkeğin karşısına bir görev olarak çıkmaktadır. Erkek, 'erkekçe’ var olabilmek için bu görevleri yerine getirmek zorundadır. Türkiye'de de pek çok fark$l_{1}$ erkeklikten ve erkekliklerden bahsedilebilir olmasının yanında, topluma egemen olmuş tek bir erkeklik algısı kendisi dışındaki çeşitli erkekliklerin varlığıyla kendini güçlendirmekte ve bu farklı erkeklikleri ötekileştirmektedir. Onur ve Koyuncu'ya ${ }^{60}$ göre, erkekler, "erkek gibi erkek”, "erkekler ağlamaz", "acı çeken erkek dişini sıkar" veya "erkek gibi davran" şeklinde telkinlerle, samimiyet, yaratıcılık, duyguları ifade etme gibi konularda kendisini frenlemek zorunda hisseder. Sorunların çözümünde yabancı bir kişiden yardım talebinin dahi güçsüzlük olarak değerlendirilmesi, erkeklerin ne denli ben merkezli bir güçlülük algısına sahip olabileceklerini göstermektedir. Romanda Türk erkekleri ile ilgili tespitler, erkek ve güç ilişkisine ışı tutmaktadır:

Türk erkekleri, sünnetin onları AiDS’ten de koruduğuna inanırlardı. Bu yüzden önce Karadeniz kıyllarımı, sonra da İstanbul başta olmak üzere bütün büyük şehirleri ve Antalya gibi kıyı kentlerini dolduran binlerce Rus kızıyla yatarken hiç kimse tedbir almazdı. Çünkü sünnetli olmak korurdu onları. On yıllarca önce köylere ilk kez elektrik geldiğinde, o tellere dokunmanın insanı öldüreceği uyarısı üzerine birçok erkek, "Yiğit adam şuncacık telden mi korkar?" diye elalemin gözü önünde elektrik tellerine sarılmış, sonra da dişleri takırdayarak ve zangır zangır titreyerek telef olup gitmişti. AiDS'ten korkmak da Türk erkeğinin kendisine yakıştırabildiği bir davranış değildi.

Türk erkekleri ile ilgili bu tespitler, erkeğin yetersiz bulunmaya dair korkusunun ne kadar yaygın olduğunu da düşündürmektedir. Onur ve Koyuncu’ya göre, erkek çocuklarının kendi cinsiyetlerine ait kişiler tarafından aşağılanmamak için, belli bir yaştan sonra kadınlarla arasına mesafe koymak ve yeni biçilen rolleri üstlenmesi de gerekmektedir. Aksi takdirde, "kılıbık", "ana kuzusu", "muhallebi çocuğu" gibi etiketlerle alaya alınırlar Sökmen ${ }^{61}$, her erkeği bir anne doğurmuşken, bir erkeğin ana kuzusu olarak etiketlenmesine dikkat çekmekte ve erkekliğin dövmek, sövmek, hakim olmak gibi fiillerle özdeşleştirildiğini ve "ölebilen ve öldürebilen" er kişi olarak top-

59 Barutçu, “Türkiye’de Erkeklik İnşasının Bedensel ve Toplumsal Aşamaları”, 7.

60 Hilal Onur ve Berrin Koyuncu, "Hegemonik Erkekliğin Görünmeyen Yüzü: Sosyalizasyon Sürecinde Erkeklik Oluşumları ve Krizleri Üzerine Düşünceler”, Toplum ve Bilim Dergisi 101 (2004): 43.

61 Semih Sökmen, "Bu sayıda”, Toplum ve Bilim Dergisi 101 (2004): 3. 
lumda yer bulduğunu ifade etmektedir. Romanda sözü edilen Mammasimo kavramı bu duruma örnek oluşturmaktadır:

Gerçi Profesör böyle düşünüyordu ama can çıkar huy çıkmaz misali bir yandan da kafasının gerilerinde o alaycı kişilik dilini çıkarıp duruyor ve ona Newsweek dergisinde geçenlerde okuduğu, İtalya'da anneleriyle birlikte yaşayan yaşı ilerlemiş erkekler için "Mammassimo" deyiminin türetildiğini anlatan yazıyı hatırlyyordu. Herhalde bu deyim Türkçe’ye, "muhallebi çocuğu” ya da "ana kuzusu" olarak çevrilebilirdi. Ama ne mammassimo onu rahatsiz ediyordu ne de muhallebi çocuğu ya da ana kuzusu. Bir kere yenilgiyi kabul etmişti ya artık hayat onu istediği kadar parçalayabilir ve ayaklar altına alabilirdi. Oyunu en alttan açmanın da bir zevki vardı elbette. Güldü.

Romanda, Profesör İrfan Kurudal'ın erkeklik algısının geleneksel erkeklik algısından sıyrıldığını görmekteyiz. Günümüz toplumlarında yaşanan değişimlerin etkisiyle geleneksel kadınlık ve erkeklik rollerinin etkisini yitirmesi ve cinsiyet rollerinin yeniden sorgulanmasıyla birlikte, hem çalışma yaşamında hem de ailede giderek egemenliğini kaybeden erkeklerle karşılaşılmaktadır. Geleneksel anlamda kurulan erkekliğin, tıpkı kadınlık gibi, yaşanan toplumsal dönüşümler ve yeniden sorgulanan, üretilen roller doğrultusunda egemenliğini kaybetmeye başladığı görülmektedir. Erkeklik kendini yeniden tanımlamakta, farklı erkeklikler ortaya çıkmaktadır. Günümüzde diğer toplumlarda olduğu gibi, Türk toplumunda da ortaya çıkan bu yeni erkeklikler dikkatleri üzerine çekmektedir. ${ }^{62}$ Romanda, Meryem'in köyde karş1laştığından farklı, yeni erkekliklere de rastlanmaktadır:

Adaleleri, çevik ve kıvrak hareketlerini kaş altından süzüyor ve hayran kalıyordu. Kasabada böyle bir şeye asla cesaret edemez, aklından bile geçiremezdi ama zaten oradaki erkekler, bu çocuklara benzemiyorlardı. Bambaşka bir dünyaya gözlerini açmıştı Meryem ve bu dünya kendi tanıdı̆̆ından tamamen farklıydı.

Meryem bir yandan da insanın iyi şeylere ne çabuk alıştığına hayret ediyordu. Bir haftadan beri erkeklerin içinde yemek yiyor, su içiyor ve artık bundan hiç utanmıyordu. Oysa genç kızlı̆̆a adım attı̆̆ı günden beri öğrendiği şey, erkeklerin yanında yemek yenilemeyeceğ $i$, su içilemeyeceğ $i$, helaya gidilemeyeceğ $i$, hatta konuşulmayacağıydı. Oysa şimdi yol üstü lokantalarında Cemal'le karşılıklı oturup hiç konuşmadan çorba içiyorlardı; hem de onca insanın içinde. Daha sonra Cemal benzin istasyonunun yanındaki erkekler helasına gittiğinde kendisi de hiç utanmadan kadınlar bölümüne giriveriyordu. Sanki ömrü boyunca böyle yaşamıştı.

Meryem'in yaşadığ 1 arada kalmışlık Türkiyede köy ile kent arasındaki tutum ve yaşayış biçimi farklılıklarına da işaret etmektedir. Modernleşme çabalarını sürdüren Türk toplumunda uzun yıllardır arada kalmışlık devam etmektedir. Türk insanı hemen hemen her alanda, geleneksel değerlerle modern değerler arasında sıkışıp kalmıştır. Geleneksel erkeklik tanımının artık çağın gereklerine uymadığı, kadınların kafasın-

62 Zeybekoğlu, “Toplumsal Cinsiyet Rolleri Bağlamında Türk Toplumunun Erkeklik Algısı”, 6. 
daki erkek tipinin ise yapay ve kadınlar tarafından oluşturulmuş olduğu için gerçeği yansıtmadığ 1 söylenmektedir. ${ }^{63}$ Bugün Türkiyede kentleşme ve ekonomik gelişmenin doğal bir sonucu olarak yoğun bir şekilde yaşanan sosyal değişme süreci, geleneksel görev paylaşımında, kadına ve erkeğe özgü rollere ilişkin ya tutumları değiştirmiş ya da modernleştirmiştir. ${ }^{64}$ Romanda Meryem'in kendi gördüğü erkeklerden farklı davranan İrfan Kurudal ile karşılaştığında şaşırması bu durumla ilişkili görülmektedir:

Meryem sadece erkeklerle bir arada yemek yemekle kalmamış, şimdi de kendisine hizmet eden, yaptı̆̆ı yemekleri tabağına dolduran bir adamla karşılaşmıştı. Hem de şehirli, okumuş yazmış, üniversite hocası ve yaşlı başlı bir adamla. Bu yüzden oturduğu sandalyede huzursuzca kıpırdand, adam eğilip tabağına yemek koyarken ne yapacă̆ını bilemedi, gözlerini başka yerlere kaydırdı, bir-iki anlamsız ses çıktı ăgzından. Ömründe ilk kez, yemek yapan ve hizmet eden bir adam görmenin şaşkınlı̆̆ıyla tabağına ne konulduğunu bile anlayamadı. Meryem kadar olmasa bile Cemal de şaşkındı. Profesör niye onları ısrarla yemeğe çağırmıştı, anlamıyordu. Böyle büyük bir adam onlarla niye arkadaşlık etmek iştesindi ki. Askerdeki komutanlarından bile daha önemli, daha büyük bir adamdı bu; koskoca üniversite hocasıydı. Ayrıca babası yaşındaydı.

Bulaşıkları bitirip güverteye çıkan ve sessizce bir köşeye ilişen Meryem ise iç bayıltıcı yasemin kokulan arasında, bu tekne ziyaretinin hiç bitmemesini diliyor$d u$. Ne güzel, ne temiz, ne farklı bir yerdi burası. Kulübeye de benzemiyordu, Rahmanlidaki gecekonduya da. Adam bugüne kadar tanıdiğı bütün erkeklerden farklıydı. Kendisine saygı gösteriyor ve belki de ondan hoşlanıyordu.

Elbette romanda İrfan Kurudal'ın temsil ettiği erkeklik, ait olduğu sınıf ve sahip olduğu statü ile yakından ilişkilidir. Cemal'e yüklenen erkeklik ile İrfan Kurudal'a yüklenen erkeklik imajı birbirinden farklıdır. Ayrıca İrfan Kurudal’ın sınıfsal karşılaşmaları ve statüsünün gerektirdiği erkeklik temsili de Cemal'den farklıdır. Bourdieu'ya göre, cinsiyetler arası farklılıklar sınıfa ve sınıfsal statüye göre de değişir (Bourdieu'den aktaran, Demez ${ }^{65}$ ). Örneğin şiddete sessiz kalarak boyun eğmek, kırsal yerleşim bölgelerinde daha fazla görülmekte ve alt sosyo-ekonomik tabakada cinsiyet rolleri bakımından daha baskın bir yönelim görülmektedir. ${ }^{66}$ Günümüz kentsel yaşamında, okul, işyeri, sivil toplum örgütleri, medya vb. birçok toplumsal oluşum bireylerin toplumsallaşma sürecine doğrudan ya da dolaylı katkı yapmaktadır. Kentsel alanlarda yaşayan bireyler açısından avantajlı bir toplumsallaşma firsatı yaratan bu imkânlar, kırsal alanlarda yaşayan bireyler açısından farklılıklar, belki de bazı eşitsizlikler yaratmaktadır. Kentsel ve kırsal alanlarda oluşan bu farklılık ve olası eşitsizliklerin nedenlerini toplumsal ve kültürel normlar, mesleki statüler, sanayileşme ile gelişen işbölümü ve ihtisaslaşma gibi birçok sosyo- ekonomik ve sosyo-

63 Zeybekoğlu, “Toplumsal Cinsiyet Rolleri Bağlamında Türk Toplumunun Erkeklik Algısı”, 9.

64 Gülay Günay ve Özgün Bener, "Kadınların Toplumsal Cinsiyet Rolleri Çerçevesinde Aile İçi Yaşamı Algılama Biçimleri”, TSA, 15/3 (2011): 159.

65 Demez, Kabadayıdan Sanal Delikanlıya Değişen Erkek İmgesi, 71.

66 Serdar Tekeli, “Toplumsal Cinsiyet Çerçevesinde Kadın Mağduriyeti”, 52. 
kültürel faktörlerle ilişkilendirmek mümkündür. ${ }^{67}$ Romanda, Meryem'in İstanbul'a götürülmek üzere bindiği trende karşılaştığı kadınlar, farklı sınıflardan kadınlardır. Sosyo-ekonomik düzey, sınıf ve köylü-kentli olma ayrımı, kadınların toplumsal cinsiyet rollerine de yansımakta ve bu rollerde farklılık yaratmaktadır. Toplumun kentli kadından ve köylü kadından "kadınlığın gereklerine" dair farklı beklentileri söz konusudur. Meryem'in trende karşılaştı̆̆ı kadınlar, bu yüzden ona tuhaf ve yabancı gelmektedir:

Gece tıkır tıkır giden trenin sallantısında içi geçip de uykuya dalmadan önce, trende gördüğ̈̈ kadınları düşünmüştü. Onların her bir ayrıntısı kafasına kazınıyor, parmaklarındaki ojeler, yüzükler, dar pantolonlarının kalçalarına oturuşu ya da dizlerinin biraz üstünde biten siyah eteklerin açıkta biraktı̆̆ı bacaklarının beyazlığı, serbest tavırları, saçlarını şöyle bir savurup düzeltmeleri aklından çıkmiyordu. Hele Seherin trende, anasinın ve babasinin yanında o yabancı erkekle çatır çatır kavga etmesi, ona öfkelenmesi müthiş bir şeydi. Onu izlerken içi heyecanla dolmuştu Meryem in. Adam, onca lafi işitmesine ve yüzüne karşı bağırılmasına răgmen Seherse elini kaldırıp vuramamış, onu ayakları altına alıp çiğneyememiş, üstüne üstlük bir de babasından tükürük yemişti. Ne acayip bir dünyaydı bu böyle. Oysa kendileri erkeklerin yanında konuşamaz, yemek yiyemez, tuvalete gittiğini belli edemez, hatta gebeliklerini bile saklarlardı. Bir kız bir eve gelin gidip de hamile kaldı mi, bu ayıb aylarca herkesten gizlerdi ve kayınvalidesi, ancak kızın turşu ve nar ekşisine aşırı düşkünlük göstermesi gibi belirtilerden anlayabilirdi durumu. Kız son güne kadar sesini çıkarmadan, yakınmadan çalışmaya devam eder ve saati gelince eve gelen ebe, sessiz sedasız doğumu gerçekleştirirdi. Aynı şey Seherin başına gelse herhalde davul zurnayla ilan ederdi bu durumu ve ailesi onu nazlardı da nazlardı. Ama kendi durumundaki ani değişme de pek fena sayılmazdı doğrusu. Hayatında ilk kez, garajda, erkeklerin ve Cemalıin yanında yemek yemişti.

Güneşten esmerleşmiş bacaklarını çıplak bırakan ve kalçalarında biten şortlarla, özgürce saldıkları saçlarını rüzgârda savura savura gururla -kadınlıklarından hiç utanmadan-yürüyorlardı. Meryem bu kızlara hayran kaldı. Ve belki de ömründe ilk kez, genç erkeklere alıcı gözüyle bakabildi.

Meryem, hayatında ilk kez kendisine sen değil de siz diye hitap edildiğinin farkına varmıştı. Acaba mucize dedikleri bunlar mıydı? Erkeklerin yanında çıplak kadın resimlerine bakan bir sarışın kadın, erkeklerle kavga eden bir başka kadın, kendisine siz diye seslenilmesi. Bunlar miydı mucize?

Meryem'in kendi sınıfsal düzeninden ayrılıp, farklı kesimlerden insanlarla karşılaştığında yaşadıkları, Türkiye'de farklı kadın hallerine de ışık tutmaktadır. Kadının bir kimliğe sahip oluşunun belirli kesimlere özgü olduğu anlaşılmaktadır.

Toplumsal cinsiyetle ilgili var olan kalıp yargılar, kadın ve erkek ilişkilerinde cinsel-

67 Pınar Gülbaş. "Kırsal ve Kentsel Alanlarda Toplumsallaşma Süreci ve Toplumsal Cinsiyet Rollerinin Kazanılması” (yüksek lisans tezi, Süleyman Demirel Üniversitesi, 2013): 7. 
liğe ve romantik ilişkilere ilişkin de olabilmektedir. Türkiye’de yaygın bir geleneksel anlayışa göre, "kadın erkeği elinde tutabilir”. Bu kalıp yargı temelde, erkeği eve bağlamanın kadının başarısı olarak görülmesi ile ilişkilidir. Toplumsal cinsiyet bağlamında bakıldığında, kadın erkeğin kendisine olan bağlılığını "kazanmaya" çabalarken, erkeğin kadının bağlılığını kazanması tartışılmaz. Kadın zaten ilişkiye ve erkeğe bağlı olarak algılanmaktadır. Glick ve Fiske'ye ${ }^{68}$ göre, dostça cinsiyetçilik kadını geleneksel rolleri ile yüceltir ve kişilerarası ilişkilerde kadının erkeğe bağlılığını vurgular. Düşmanca cinsiyetçilik ise, kadının erkeğe göre daha zayıf ve erkeğe bağımlı olarak algılanması ve buna bağlı olarak da düşük seviyede görülüp cinsiyet ayrımcılığına maruz kalması şeklinde tanımlanır. Cinsiyetçiliğin örtük bir biçimde ifade bulduğu korumacı cinsiyetçilik ise kadınların zayıf, bağımlı ve korunması gereken varlıklar olarak gösterilip diğer taraftan örtük olarak geleneksel cinsiyet kalıp yargılarının ve erkeksi baskınlığın vurgulanmasıdır. Sakallı ve Curun $(2001)^{69}$, sosyalleşme sürecinde çoğu kadına 'bir gün beyaz atlı prenslerinin gelip, onları bulacağı' inancının bilinçli veya bilinçsiz bir şekilde aşılandığı görüşünden söz etmektedir. Romanda, bir kalıp yargı olarak kadınların bir erkeğe "sahip olma ve onu elde tutma" amaçlarının, Büyükelçi ağzından yansıtıldığı görülmektedir:

Büyükelçi, "Romantizm Avrupa’nın icadıdır ama buralarda da taklit edilmeye çalışılır. Evli kadınlar romantizme çok meraklıdır. Ne demektir bu: Karı koca para kavgası yapacaksınız, arada bir bă̆ırsaklarınızın bozulduğundan şikâyet edeceksiniz, hangi ilacın gaza daha iyi geldiğini konuşacaksınız; sonra bütün bunlar bir anda bitecek ve mum ışığında karşılıklı göz göze bakarak birbirinize ayılıp bayılacaksınız. Bunun da adı romantizm saati olacak. Hiç böyle şey olur mu?” Profesör, bu sözlere yere yıkılacak kadar gülüyordu. "Bu dünyada her kadının bir tek amacı vardır: Ömrünün sonuna kadar dizinin dibinde oturtabileceği bir erkeğe sahip olmak!”

Büyükelçi, "İnsanoğlu, homo erectus olduğu andan itibaren kadınların vajinası darald," dedi. "Bu yüzden insanın dişisi çok zor doğurur. Hamileliği ağır geçer, bebeği de diğer hayvan yavruları gibi doğar doğmaz yürüyemez. Bakıma ihtiyacı vardır. Eee mağarada geçen uzun hamilelik ve annelik günlerinde aileyi kim besleyecek, kim av eti getirecek? Tabi ki bir erkek. Kendisini o aileye adamış bir adam. Bu sebeple mağara devrinden beri dünyanın bütün kadınlar, bütün erkeklere üç soru sorarlar: Nereye gidiyorsun? Ne zaman geleceksin? Beni seviyor musun? Bu iş mağara devrinde böyleydi, günümüzün New York’unda da, Paris' inde de, İstanbul'unda da böyle!”

Kadınla ilgili kalıp yargıların, romanda, hem alt hem üst sosyo-ekonomik düzeyden kişiler veya hem okumamış hem aydın kişiler tarafından farklı biçimlerde yinelendiği görülmektedir. Roman bu yönüyle, Türkiye’de kadının konumuna ve statüsüne ilişkin daha çok yol alınması gerektiğine işaret etmektedir.

68 Peter Glick ve Susan T. Fiske, "An Ambivalent Alliance. Hostile and Benevolent Sexism as Complementary Justifications for Gender Inequality", American Psychological Association, (Feb. 2001): 109.

69 Nuray Sakallı ve Ferzan Curun, "Romantik İlişkilerle İlgili Kalıp yargılara Karşı Tutumlar”, Tecrübi Psikoloji Çalışmaları (2001): 42. 


\section{Sonuç ve Değerlendirme}

Bu çalışmanın amacı Zülfü Livaneli'nin "Mutluluk” adlı romanında yer alan karakterlerin toplumsal cinsiyet rolleri bağlamında incelenmesidir. Romanda, yaşadığ1mız toplumda kadının ve erkeğin rolleri ve konumu, toplumun "töre", "namus" gibi kavramlara verdiği önem, karakterlerin söylemleri ve yaşantıları aracılı̆̆ıla vurgulanmaktadır. Romanın kahramanlarından biri olan Meryem, amcası tarafından tecavüze uğramış ve ailesinin kararına göre “ölümü hak etmiş” bir kadındır. Çünkü o "artık kirlenmiştir" ve tecavüze uğramış olması ölmesi gerektiği gerçeğini değiştirmeyecektir. Meryem’i öldürmesi gereken kişi de amcasının oğlu Cemal'dir. Roman$\mathrm{da}$, toplumsal cinsiyet rolleri gereği doğduğu günden beri yaşamının birçok alanında erkeğin gerisinde kalmak zorunda bırakılan kadınlar, erkeğe hizmet etmesi gereken, iyi bir eş, iyi bir anne olması gereken bireyler olarak resmedilmektedir. Bu gibi sorumlulukları dışında kadın, çoğu kez "cinsellik" ile ilişkilendirilen "namus"una sahip olmalı ve bekâretini korumalıdır. Aksi takdirde kadın bunun bedellerine katlanmak zorundadır. Kadının namusundan sorumlu olan kişi de ailedeki erkektir. "Mutluluk" romanında da olduğu gibi tecavüze uğradığı için “ailenin namusunu kirleterek” ölümü hak eden Meryem ile onu öldürmesi kişi olan Cemal’e yapılan baskı toplumsal cinsiyetin ağır bedellerini yansıtmaktadır. Görülmektedir ki toplumsal cinsiyet rolleri hem kadın hem de erkek üzerinde baskı oluşturmaktadır.

Sonuç olarak "Mutluluk” romanı, "tecavüz", "töre”, "namus” gibi kavramlar konusunda toplumun önemli bir gerçekliğini yansıtmakta ve kadına ve erkeğe yönelik toplumsal cinsiyet rollerinin getirdiği baskıyı gözler önüne sermektedir. Toplumsal cinsiyet rollerinin, Türkiye'de erkekliğe ve kadınlığa yüklenen anlamların, erkek ve kadınla ilgili kalıp yargıların karakterlerin konuşmalarında veya yaşantılarında açıkça göze çarptı̆̆ bu eserin toplumsal cinsiyet konusunun anlaşılmasında önemli bir kaynak olduğu düşünülmektedir. Romanın, özellikle Türkiye’nin farklı bölgelerinde kadının ve erkeğin konumsal farklılıklarına getirdiği bakış açısı, toplumsal cinsiyetin kadını ve erkeği nasıl etkilediğini anlamada farklı bir perspektif sunmaktadır.

\section{Kaynakça}

Akaltun, Ayşe. “Fotoğraf Karesi”. Erkekler. Haz., Ayşe Akaltun. İstanbul: Notabene Yayınları, 2015.

Akçay, A. Adnan. “Arzu, Cinsellik ve Erkekler”. Erkekler. Haz., Ayşe Akaltun. İstanbul: Notabene Yayınları, 2015.

Akın, Galip. “Toplumsal Cinsiyet ve Edebiyat”. Erkekler. Haz., Ayşe Akaltun. İstanbul: Notabene Yayınları, 2015.

Atebek, Erdal. Kışkırtılmış Erkeklik Bastırılmış Kadınlık. İstanbul: Cumhuriyet Kitapları, 2015.

Barutçu, Atilla. “Türkiye’de Erkeklik İnşasının Bedensel ve Toplumsal Aşamaları”. Yüksek lisans tezi, Ankara Üniversitesi, 2013.

Baydar, Veysi. “Popüler Kültürde Mizojini”. Turkish Studies 8/151 (Güz 2013): 151165. 
Bilgili, Naile ve Gülşen Vural. "Kadına Yönelik Şiddetin En Ağır Biçimi: Namus Cinayetleri”. Anadolu Hemşirelik ve Sağlık Bilimleri Dergisi 14/1 (2011): 66-72.

Bingöl, Orhan. "Toplumsal Cinsiyet Olgusu ve Türkiyede Kadınlı". KMÜ Sosyal ve Ekonomik Araştırmalar Dergisi 16 (Özel Sayı I, 2014): 108-114.

Boyd, Monica, "Gender Inequality: Economic and political Aspects”, edt., Robert J. Brym, New Society: Sociology for the 21st Century. Toronto: Harcourt Brace\&Company, 1998.

Bozok, Mehmet. "Profeminizm, Ben ve Kendim”. Erkekler. Haz., Ayşe Akaltun İstanbul: Notabene Yayınları, 2015.

Coleman, James William \& Kerbo, Harold R. Social Problems: A Brief Introduction, Second Edition. New Jersey: Prentice Hall, 2003.

Connell, Richard W. Toplumsal Cinsiyet ve İktidar, Toplum, Kişi ve Cinsel Politika. Çev. Cem Soydemir. İstanbul: Ayrıntı Yayınları, 1998.

Çoklar, Işıl ve Meşe Gülgün. "Illinois Tecavüz Mitlerini Kabul Ölçeği Kısa Formunu Türkçe’ye Uyarlama Çalışması”. Psikoloji Çalışmaları Dergisi 34/2 (2014): 53-64.

Demez, Gönül. Kabadayıdan Sanal Delikanlıya Değişen Erkek İmgesi. İstanbul: Babil Yayınları, 2005.

Demirbilek, Sevda. “Cinsiyet Ayrımcılığının Sosyolojik Açıdan İncelenmesi”, Finans Politik \& Ekonomik Yorumlar 511 (2007): 12-27.

Demren, Çağdaş. “Ortadoğu’da Ataerkillik ve Erkeklik İlişkileri” C.Ü. Sosyal Bilimler Dergisi 32/2 (Aralık 2008): 321-329.

Ecevit, Yıldız. “Toplumsal Cinsiyetle Yoksulluk İlişkisi Nasıl Kurulabilir? Bu İlişki Nasıl Çalışılabilir?” C. Ü. Tip Fakültesi Dergisi 25/4 (2003 Özel Ek): 83-88.

Eker, Tuğba ve Eda Erdener. “Tecavüze İlişkin Kültürel Mitler ve Mitlerin Kabul Edilmesine Etki Eden Faktörler”, Türk Psikoloji Yazıları 14/28 (Aralık 2011): 6072 .

Etyang, Philip, Kisa, Amateshe ve Jks, Makokha. Misogyny in Urban Fiction : A Study of Selected Texts by Meja Mwang, United States: Scholars' Press, 2015.

Glick, Peter ve Fiske, Susan T. "An ambivalent alliance. Hostile and benevolent sexism as complementary justifications for gender inequality". American Psychological Association 56/2 (Feb. 2001): 109-118.

Goldberg, Herb. Erkek Olmanın Tehlikeleri, çev., Selçuk Budak, (Ankara: Öteki Yayınevi, 1994).

Gülbaş, Pınar. "Kırsal ve Kentsel Alanlarda Toplumsallaşma Süreci ve Toplumsal Cinsiyet Rollerinin Kazanılması”. Yüksek lisans tezi, Süleyman Demirel Üniversitesi, 2013.

Günay, Gülay ve Özgün Bener. "Kadınların Toplumsal Cinsiyet Rolleri Çerçevesinde Aile İçi Yaşamı Algılama Biçimleri”. TSA , 15/3 (2011): 157-171.

Işık, Ruşen ve Nuray Sakallı Uğurlu. "Namusa ve Namus Adına Kadına Uygulanan Şiddete İlişkin Tutumlar Ölçeklerinin Öğrenci Örneklemiyle Geliştirilmesi”. Türk Psikoloji Yazıları 12/24 (Aralık 2009): 16-24. 
Kandiyoti, Deniz. Erkeklik Paradoksları: Ayrımcılığın Yaşandığı Toplumlar Üzerine Bazı Düşünceler”. Cariyeler, Bacılar, Yurttaşlar, çev. A. Bora ve diğerleri. İstanbul: Metis Yayınları, 1997.

Kitiş, Yeter ve Sema Şanlıŏlu Bilgici. "Bir Aile İçi Şiddet Olgusu; Sır Tutma İlkesi ile Şiddeti İhbar Etme Yükümlülüğü Arasındaki Etik İkilem”. Aile ve Toplum 3/11 (2007): 7-11.

Koçtürk, Tahire. A matter of honor: Experience of Turkish women immigrants, London: Atlantic Highlands, 1992.

Livaneli, Zülfü. Mutluluk. (92. Baskı). İstanbul: Doğan Kitap, 2015.

Mardin, Şerif. Türk Modernleşmesi: Makaleler 4. İstanbul: İletişim Yayınları, 1991.

Marshall, Tim. Hükmeden Erkek Boyun Ĕ̆en Kadın, İstanbul: Altın Kitaplar Yayınevi, 1997.

Nüfus Bilim Derneği, “Türkiye’de Namus Cinayetlerinin Dinamikleri”, Haz., Filiz Kardam (Ankara: Nüfus Bilim Yayınları, 2005): 16.

Okyay, Gaye. "Women Victimization: In The Case of Family Honor in Turkey". Yüksek lisans tezi, Orta Doğu Teknik Üniversitesi, 2007.

Onur, Hilal ve Berrin Koyuncu. "Hegemonik Erkekliğin Görünmeyen Yüzü: Sosyalizasyon Sürecinde Erkeklik Oluşumları ve Krizleri Üzerine Düşünceler”. Toplum ve Bilim Dergisi 101 (2004): 31-49.

Ökten, Şevket. “Toplumsal Cinsiyet ve İktidar: Güneydoğu Anadolu Bölgesi'nin Toplumsal Cinsiyet Düzeni” Uluslararası Sosyal Araştırmalar Dergisi 2/8 (2009): 302-312.

Sakallı, Nuray ve Ferzan Curun. "Romantik İlişkilerle İlgili Kalıp yargılara Karşı Tutumlar”. Tecrübi Psikoloji Çalışmaları (2001): 31-45.

Sakallı-Uğurlu, Nuray, “Cinsiyetçilik: Kadınlara ve Erkeklere İlişkin Tutumlar ve Çelişik Duygulu Cinsiyetçilik”. Türk Psikoloji Yazıları 6/11 (2003): 1-11.

Sakallı-Uğurlu, N., Yalçın, Z.S. \& Glick, P. “Ambivalent Sexism, Belief in a Just World, and Empathy as Predictors of Turkish Students' Attitudes Toward Rape Victims". Sex Roles 57 (2007): 889-895.

Sancar, Serpil, Selma Acuner, İlknur Üstün, Aksu Bora. “Cinsiyet Eşitsizliği Bir Kadın Sorunu Değil, Toplumun Sorunudur”, UNDP-Kalkınma ve Demokratikleşme Projelerinde Cinsiyet Eşitliği Hedefinin Gözetilmesi Eğitimi 2005-2006, (UNDP, İstanbul 2006).

Scott, Joan W. Toplumsal Cinsiyet: Faydalı Bir Tarihsel Analiz Kategorisi, çev., Aykut Tunç Kılıç. İstanbul: Ayrıntı Yayınları, 2007.

Serdar Tekeli, Esra. “Toplumsal Cinsiyet Çerçevesinde Kadın Mağduriyeti”. Yüksek lisans tezi, Ankara: Polis Akademisi, Suç Araştırmaları Anabilim Dalı, 2011.

Sır, Aytekin. “Namusun Algılanışı”. İstersek Biter. Haz., Aksu Bora. İstanbul: KAMER Vakfı Yayınları, 2011.

Sokullu Akıncı, Füsun, Kriminoloji. İstanbul: Beta Basım Yayım, 2011.

Sökmen, Semih. "Bu sayıda". Toplum ve Bilim Dergisi, 101 (2004): 3. 
Sullivan, Thomas J. Introduction to Social Problems, Sixth Edition. Boston: Pearson Education, 2003.

Şeker, Mustafa, İbrahim Torukve Rengim Sine. “Töre Cinayetlerinin Türk Medyasında Sunumu: Mardin Katliamı", Global Media Journal 3 (2013): 166-195.

Taş, Murat. "Mutfak”. Erkekler. Haz. Ayşe Akaltun. İstanbul: Notabene Yayınları, 2015.

Terzioğlu, Füsun ve Lale Taşkın. "Kadının Toplumsal Cinsiyet Rolünün Liderlik Davranışlarına ve Hemşirelik Mesleğine Yansımaları”. C.Ü. Hemşirelik Yüksekokulu Dergisi 12/2 (2008): 62-67.

Tezcan, Mahmut. "Ülkemizde aile içi töre ya da namus cinayetleri”. T.C. Başbakanlık Kadının Statüsü ve Sorunları Genel Müdürlüğ̈̈ içinde (21-27). Ankara: T.C. Başbakanlık Kadının Statüsü ve Sorunları Genel Müdürlüğü, 1999.

Tezcan, Mahmut. Türkiye’de Töre (Namus) Cinayetleri: Sosyo-Kültürel Antropolojik Yaklaşım. Ankara: Bahar Kitabevi, 2003.

Yaşın Dökmen, Zehra. Toplumsal Cinsiyet: Sosyal Psikolojik Açıklamalar. İstanbul: Remzi Kitabevi, 2015.

Yüksel N., Aysun. Tarkan Yıldız Olgusu. İstanbul: Çivi Yazıları, 2001.

Zeybekoğlu Özge, “Toplumsal Cinsiyet Rolleri Bağlamında Türk Toplumunun Erkeklik Algısı”. ETHOS: Felsefe ve Toplumsal Bilimlerde Diyaloglar 3 (Kış 2010).

Zeybekoğlu, Özge. Toplumsal Cinsiyet Bağlamında Erkeklik Olgusu. Ankara: Eğiten Kitap, 2013. 


\title{
Analysis of the Fictitious Characters of Zülfü Livaneli's Novel "Bliss" in Terms of Gender
}

\author{
ÖZLEM HASKAN AVCI \\ MUHARREM KOÇ \\ ÖZNUR BAYAR
}

\begin{abstract}
Literature and literary, has always been and always will continue to be in the lives of individuals and community and it's an area for expressing intensively about community specific cultural elements. Novel, in many ways reflects individual's and society's characteristics as a literary work. In this study, representative of different femininity and masculinity on Zülfü Livaneli's novel Bliss' characters were aimed to investigate within the context of gender. In the novel, Meryem who was raped by her uncle, was claimed to 'needs to be killed' because of so-called honor and also due to this understanding, this task was found appropriate for Meryem's uncle's son, Cemal. The novel reflects the pressure on women and gender discrimination. In this novel women seems to be the symbol of honor and men seems to be responsible for this honor. Writer highlights the pressure on men and women caused by gender roles. In this study, gender and gender roles in Turkey were discussed and increasing awareness of gender and gender roles were aimed.
\end{abstract}

Keywords: Zülfü Livaneli, Bliss, gender, gender role. 